\title{
PERSPECTIVAS SOCIAIS E DOMINAÇÃO SIMBÓLICA: A PRESENÇA POLÍTICA DAS MULHERES ENTRE IRIS MARION YOUNG E PIERRE BOURDIEU
}

\author{
Luis Felipe Miguel
}

\begin{abstract}
RESUMO
O artigo trata da participação política das mulheres e de sua presença no poder político. Nessa temática, discute a tensão entre o potencial emancipacionista prometido pela incorporação de múltiplas perspectivas ao debate político e a ação reprodutora do campo. Partindo das causas que, a nosso ver, são responsáveis pela relativa ausência de mulheres dos círculos decisórios e por seu "desinteresse" pela politica, discutimos as perspectivas orientadas, de uma forma ou de outra, para a solução (melhoramento) dessa situação. O artigo organiza-se em três seções. Na primeira, defende-se a posição de que a via mais promissora para justificar a necessidade de presença das mulheres passa pelo entendimento de que os espaços de deliberação devem abrigar uma pluralidade de perspectivas sociais relevantes - um conceito associado, sobretudo, à obra da teórica estadunidense Iris Marion Young. Na segunda, discute-se alguns problemas desse conceito, em especial, certa ingenuidade que marca um ideal dele derivado: a geração de um espaço plural de discussão e de tomada de decisão em função da adoção de cotas eleitorais. Utiliza-se o conceito de "campo", extraído da obra de Pierre Bourdieu, para depurar as idéias de Young dessa ingenuidade. Na terceira seção, introduz-se um elemento adicional: a distinção, apresentada por Nancy Fraser, entre "politicas afirmativas" e "políticas transformadoras". Conclui-se, de forma preliminar, com um balanço dos limites e das potencialidades de uma política baseada na defesa da ampliação da presença de "perspectivas sociais".
\end{abstract}

PALAVRAS-CHAVE: perspectiva social; campo político; representação política; Iris Marion Young; Pierre Bourdieu.

\section{INTRODUÇÃO}

Nas últimas décadas, a fraca presença de mulheres nos espaços de tomada de decisão afirmouse como um problema político de primeira grandeza ${ }^{1}$. A experiência das democracias eleitorais demonstrou que a mera conquista do voto feminino

\footnotetext{
${ }^{1}$ Este artigo integra o projeto "Determinantes de gênero, visibilidade midiática e carreira política no Brasil”, apoiado pelo Conselho Nacional de Pesquisa (CNPq) (editais n. 45/ 2005, 61/2005, 57/2008 e bolsa de Produtividade em Pesquisa) e pela Fundação de Apoio à Pesquisa do Distrito Federal (FAP-DF) (edital n. 5/2008). Ele beneficia-se de anos de conversas com Regina Dalcastagnè; e seu ponto de partida foram discussões com Flávia Biroli relativas à seção final do trabalho "A produção da imparcialidade" (MIGUEL \& BIROLI, 2009), que prosseguiram em vários outros momentos. Agradeço a ambas, que comentaram versões anteriores do texto e a quem devo mais do que este reconhecimento protocolar é capaz de expressar, bem como a José Szwako, que também leu uma versão prévia. Permaneço, é claro, como único responsável pelos erros e omissões remanescentes.
}

era insuficiente para eliminar a assimetria entre homens e mulheres nos cargos públicos. Da mesma forma que outros grupos sociais dominados, como trabalhadores e minorias étnicas, as mulheres enfrentam obstáculos para transformar votos em representantes.

É possível, ainda hoje, encontrar quem leia tal situação como demonstração de um desinteresse "natural" das mulheres pela política ${ }^{2}$. Uma percepção minimamente sofisticada, porém, entende que o acesso à franquia eleitoral é uma condição necessária, mas nem de longe suficiente, para se chegar às esferas de exercício do poder político. A participação política das mulheres é limitada por fatores materiais e simbólicos, que prejudicam sua capacidade de postular candidaturas, reduzem a

\footnotetext{
2 A revista Veja explicava, em 2006, que poucas mulheres eram candidatas às eleições porque "o interesse feminino pela política é muito menor do que o masculino" (POLÍTICA É COISA DE HOMEM?, 2006).
} 
competitividade daquelas que se candidatam e atrapalham o avanço na carreira política daquelas que se elegem. Principais responsáveis pela gestão das unidades domésticas e pelos cuidados com as crianças, as mulheres dispõem de menos tempo livre, que é o recurso crucial para a ação política. Também tendem a receber salários menores e a controlar uma parcela inferior de recursos econômicos. Ao mesmo tempo, o universo da política é construído socialmente como algo masculino, o que inibe o surgimento da "ambição política”, ou seja, da vontade de disputar cargos, entre elas ${ }^{3}$. Há, aqui, uma excelente ilustração daquilo que Pierre Bourdieu chamava de efeito de doxa, isto é, nossa visão do mundo social constrange nosso comportamento, comprovando (e naturalizando) aquilo que pensamos.

O reconhecimento da sub-representação política feminina como um problema a ser enfrentado levou à busca por soluções, que vão tomar, com freqüência, a forma de cotas partidárias ou eleitorais de candidaturas para mulheres. Adotadas a partir da década de 1970, sobretudo em países da Europa e da América Latina, as cotas possuem eficácia muito variável, dependendo do sistema eleitoral, da magnitude dos distritos, da fragmentação partidária e do desenho específico de cada legislação (ARAÚJO, 2001; ARAÚJO \& ALVES, 2007; MIGUEL, 2008). Mas sua adoção representa, em si mesma, a admissão de que a igualdade política entre homens e mulheres impõe um desafio que não se resolve nos limites do ordenamento liberal.

Enquanto o liberalismo julga que apenas indivíduos são sujeitos de direito, as cotas indicam a defesa do direito de um grupo (as mulheres) fazer-se representar nos espaços de tomada de decisão ${ }^{4}$. Para a filosofia liberal clássica, são os indivíduos que possuem interesses e um eventual interesse de grupo não passa da mera agregação dos interesses individuais. Acresce-se aí o princípio utilitarista de que "cada um é o melhor juiz de seus próprios interesses" - um argumento que foi

\footnotetext{
3 Dados relativos aos Estados Unidos revelam que, entre indivíduos com status profissional similar, homens apresentam uma predisposição a concorrer a eleições significativamente superior à das mulheres (FOX \& LAWLESS, 2004).

4 Este parágrafo e o seguinte resumem argumentos presentes em Miguel (2000).
}

aproveitado pelo movimento sufragista a favor do voto feminino, na recusa de posições à la James Mill, que negava a necessidade de estender a franquia eleitoral às mulheres uma vez que seus interesses estariam subsumidos nos interesses de outros (pais ou maridos). Uma vez obtido o direito de voto, porém, o argumento volta-se contra qualquer medida posterior. Se as mulheres, que são as melhores juízas de seus próprios interesses e têm direito de voto igual aos homens, querem mulheres como suas representantes, então elas elegerão mulheres. Se não o fazem, então é porque tal interesse não existe ou não é forte o bastante.

Assim, as cotas eleitorais implicam, em primeiro lugar, no reconhecimento de que a resultante das escolhas dos indivíduos pode ser perniciosa do ponto de vista coletivo, isto é, que uma assembléia formada pelo voto dos cidadãos (e cidadãs) pode, no entanto, frustrar expectativas socialmente válidas, como a presença mais ou menos proporcional de determinados grupos nos espaços de poder. Implicam também no rompimento com a separação, da qual o liberalismo sempre foi tão cioso, entre a igualdade política formal e as desigualdades sociais, assumindo que existem fatores que inibem a ação política das mulheres e que não se resolvem com a mera extensão de direitos iguais a elas. E implicam, por fim, na admissão de que políticas voltadas à proteção dos direitos desse grupo - as mulheres - são legítimas, ainda que signifiquem limitações ou cerceamento do exercício de direitos individuais.

Resulta daí que as cotas eleitorais colocam uma série de questões importantes para a teoria política, algumas das quais pretendo discutir neste artigo. Há, por trás da defesa de políticas de cotas, uma percepção específica da representação política, associada à revalorização daquilo que Hanna Pitkin chamou de "representação descritiva". No entanto, a reivindicação por presença política não deriva de maneira automática da sub-representação de um grupo. É necessário justificar por que determinada clivagem social deve estar espelhada no corpo de representantes - e as cotas para mulheres mobilizam diferentes universos de justificativas, nem sempre integralmente compatíveis entre si.

Na primeira seção do artigo, defendo a posição de que a via mais promissora para justificar a necessidade de presença das mulheres passa pelo 
entendimento de que os espaços de deliberação devem abrigar uma pluralidade de perspectivas sociais relevantes - um conceito associado, sobretudo, à obra de Iris Marion Young. Vista deste prisma, a adoção de cotas eleitorais deveria levar a determinados resultados, em particular a geração de um espaço plural de discussão e de tomada de decisão.

$\mathrm{Na}$ segunda seção, discuto alguns problemas do conceito, em especial certa ingenuidade que marca o ideal que dele deriva, como se a incorporação das diferentes perspectivas sociais fosse capaz de produzir um ambiente discursivo equânime (fruto daquilo que chamo de "crítica imperfeita" de Young ao ideário deliberativo de matiz habermasiana). Contra essa ingenuidade, introduzo o conceito de "campo", extraído da obra de Pierre Bourdieu - um pensador que, sem ser feminista, foi sensível às diferentes formas de dominação social ${ }^{5}$. A política, como qualquer outro campo social, é um espaço estruturado e estruturante das práticas daqueles que nele ingressam e nele desejam progredir. Há, portanto, um fator que gera homogeneização, conformidade a normas, a expectativas, a padrões discursivos, e neste mesmo processo perpetua a divisão entre sujeitos políticos ativos - os profissionais, aqueles que dominam os códigos do campo - e a massa de "profanos", no sentido de Bourdieu, limitados a optar entre as ofertas que lhe são apresentadas. Isso põe em xeque o potencial emancipacionista que a incorporação de múltiplas perspectivas ao debate político promete.

A terceira seção do artigo introduz um elemento adicional - a distinção, apresentada por Nancy Fraser, entre políticas "afirmativas" e políticas "transformadoras". Na qualidade de política afirmativa, a inclusão de integrantes de grupos em posição de subalternidade a determinados campos sociais não erode as estruturas da desigualdade, como a própria Fraser apontaria, e a necessidade de adaptação aos imperativos do campo reduz o potencial disruptivo que essa mesma presença traria. A análise de dois casos diversos, mas que têm em comum a exigência do domínio de certo padrão de fala - o campo literário e o cam-

\footnotetext{
$5 \mathrm{O}$ tratamento que o próprio Bourdieu dá às questões de gênero é marcado por um determinismo e uma unilateralidade excessivas (BOURDIEU, 1998a). Para abordagens críticas, cf. Corrêa (1999) e Moi (1999, p. 264299).
}

po político -, ajuda a aprofundar a discussão.

Na breve conclusão do texto, busco, de forma ainda bem inicial, fazer um balanço dos limites e das potencialidades de uma política baseada na defesa da ampliação da presença de "perspectivas sociais".

\section{REPRESENTAÇÃO E PERSPECTIVAS}

A compreensão que temos da representação política - o que ela é, o que ela deve ser, o que ela pode dar-nos - é marcada pela influência da obra de Hanna Pitkin (1967). Após uma minuciosa reconstituição do conceito, a autora faz a defesa da representação "formalista", centrada sobretudo em mecanismos de accountability que garantiriam a vinculação entre as preferências dos constituintes e as decisões dos eleitos. A partir da década de 1980, porém, há uma revalorização da representação "descritiva", que Pitkin julgava uma percepção ingênua e pouco sofisticada, revalorização baseada, por um lado, na consciência da débil realização das promessas da accountability, e, por outro, nas demandas de grupos minoritários por acesso às esferas decisórias ${ }^{6}$.

Anne Phillips reposiciona a representação descritiva em termos de "política de presença", que ela opõe à "política de idéias" subjacente ao modelo formalista dominante (PHILLIPS, 1995). A política de idéias vê os representantes como vetores descarnados de plataformas políticas, entre as quais os eleitores escolhem. Uma vez que, como cidadão, eu identifico-me com as propostas, os valores ou as políticas sugeridas por um candidato, a identidade deste candidato é irrelevante. Os mecanismos de accountability permitiriam que eu supervisionasse a ação de meu representante, garantindo que ele mantivesse-se fiel àquilo que expressou durante a campanha. Assim, o que interessa não é se mulheres são escolhidas representantes, mas se as reivindicações e interesses femininos são expressos, ainda que por homens, nos locais de deliberação.

Por vários motivos, a começar pelas assimetrias entre representantes e representados, que reduzem a capacidade de supervisão dos primeiros pelos últimos, a accountability tem dificuldade de

\footnotetext{
6 Mais recentemente, há um movimento de valorização da representação "por advocacy", que corresponderia a um terceiro grande modelo explorado por Pitkin, muito na esteira da obra de Nadia Urbinati $(2000 ; 2006)$
} 
realizar-se (MIGUEL, 2005). A adoção de mecanismos descritivos sugere que a ausência de accountability efetiva seria como que compensada por uma maior similaridade entre os tomadores de decisão e seus constituintes. Se eu não tenho como avaliar adequadamente a ação do meu representante, ao menos posso esperar que, sendo parecido comigo, ele seja sensível às minhas preferências.

Mas não é essa a linha de argumentação preferida por Phillips. A política de presença, tal como ela a apresenta, é uma exigência da igualdade política. Um representante, afinal, não é um canal neutro pelo qual passam as preferências ou os interesses de seus constituintes. Ele exerce poder. A ausência de mulheres - ou de outros grupos em posição de subalternidade política - entre candidatos e eleitos pode ser atribuída a um menor interesse pela política, mas este interesse menor já é, em si, uma marca da desigualdade. Como diz a própria autora, é natural que nem todos gostem de política, mas se "participação e envolvimento têm coincidido tão de perto com diferenças de classe, gênero ou etnicidade", então estamos diante de uma forte evidência de desigualdade política (idem, p. 32).

A ausência de mulheres no corpo de representantes contribui para perpetuar as condições de seu próprio afastamento, reafirmando a esfera pública - e a política, em particular - como território masculino. Há aqui uma questão que Phillips não desenvolve plenamente, mas que é de grande significado. A política de idéias, tal como ela define-a, tende a aceitar a visão liberal de que os interesses são constituídos de forma prévia à sua representação. Sem isso, não é possível sustentar a noção de que a identidade do representante é irrelevante. Quando entendemos, ao contrário, que os interesses não são dados, mas construções sociais, fica mais fácil perceber que a exclusão das mulheres da arena política tem impacto na forma como elas vão entender sua posição no mundo social e, portanto, seus próprios interesses.

Phillips vai argumentar, então, que não basta eliminar as barreiras formais à inclusão, concedendo acesso ao voto ou direitos iguais. É necessário incorporar expressamente os grupos marginalizados no corpo político (PHILLIPS, 1999, p. 35). São necessárias, em suma, ações afirmativas, que têm por objetivo exatamente se contra- por a padrões históricos de discriminação - ou, de forma mais precisa, opor uma força contrária à inércia gerada por tais padrões. Cotas eleitorais ou partidárias, em particular, garantiriam a incorporação das mulheres à elite política, independentemente do que pudesse aparecer como sendo a vontade delas. Mais ainda, tornariam a busca por candidatas competitivas algo do interesse também de dirigentes partidários homens (MIGUEL, 2008, p. 205).

A adoção de políticas de ação afirmativa em geral, e de cotas em particular, não é isenta de problemas, a começar pela definição de quais grupos devem ser beneficiados. Determinar que são os grupos que sofreram exclusão e/ou violência patrocinadas pelo Estado (mulheres, trabalhadores, minorias étnicas ou religiosas, minorias sexuais, deficientes físicos), como propõe Williams (1998), resolve apenas parte do problema. Primeiro, porque há grupos cuja exclusão política continua sendo determinada pelo Estado, mas a respeito dos quais, em geral, não surgem demandas por presença - caso das crianças e de residentes de outra nacionalidade. Ou seja, permanece uma discussão sobre direitos e condições de acesso a estes direitos. E, depois, porque a aplicação prática do princípio enunciado por Williams enfrenta dificuldades. Cotas para mulheres são relativamente fáceis de serem aplicadas, pois o sexo biológico pode ser tratado como uma variável dicotômica e discreta, com a proporção entre os grupos na população mantendo-se mais ou menos estável. Outras clivagens sociais significativas não possuem tais características, gerando problemas vinculados à fixação de fronteiras (quem pertence ao grupo beneficiado) e à necessidade de recalcular periodicamente o quantum de presença exigido.

A própria Anne Phillips vai apontar alguns dos problemas associados às políticas de cotas, três dos quais merecem ser destacados. Cotas em geral guardam um potencial conservador, pois tendem a perpetuar a relevância social das diferenças que elas deveriam ajudar a abolir - isto é, há algo de contraditório em fazer de sexo o critério para acesso à elite política ou de raça o critério para acesso ao ensino superior como meio para alcançar uma situação em que sexo ou raça não estejam associados à presença ou ausência nestes espaços. Cotas também não se adequam a uma realidade em que cada indivíduo possui múltiplas identidades pessoais. E cotas, agora especificamente 
as eleitorais, podem fazer com que os eleitos por meio delas sejam vistos com preconceito, como representantes de segunda linha, que não representam o povo, mas apenas as minorias às quais estão ligados (PHILLIPS, 1991, p. 153-156).

Fiel ao legado burkeano, que enfatiza que o representante representa não seus constituintes em particular, mas o povo em geral, Phillips investe contra este último ponto. Observa que a representação de grupo, tal como ela entende-a, não é uma forma de corporativismo, em que os representantes falam pelo grupo e a ele respondem. É a busca de uma distribuição mais igualitária das posições de representação entre diferentes grupos sociais, proporcionando um conjunto mais amplo de perspectivas sociais (PHILLIPS, 1999, p. 40). As cotas reservam vagas nas listas partidárias ou mesmo cadeiras no parlamento para integrantes de grupos minoritários, mas eles vão buscar o voto de todos os eleitores, indistintamente, e, tal como quaisquer outros representantes, aderem à ficção de que buscam, no exercício de suas responsabilidades, o "bem-comum", o "interesse geral" ou a "vontade do povo", e não de um segmento social em particular.

Por todos estes problemas associados à introdução das cotas, Phillips é cuidadosa ao insistir que não prega a troca da política de idéias pela de presença. Ela propõe a correção de vieses atuais da representação política por meio da adoção de mecanismos descritivos. A necessidade de supervisão dos representantes pelos representados não é abandonada. Justamente por isso, não são levadas em conta as propostas de substituição das eleições por sorteios - que escapam aos problemas das cotas descritos acima, mas, ao contrário delas, são infensos à accountability.

Como resultado, seria ampliada a pluralidade de vozes nos espaços decisórios. Phillips afirma, então, que a defesa da política de presença é parte de um deslocamento que vai do "pluralismo convencional", preocupado com grupos de interesse, ao "pluralismo radical", atento aos grupos de identidade (PHILLIPS, 1993, p. 17). Essa formulação já sinaliza a oposição entre interesses e identidades, que é crucial ao debate. Se meu interesse é representável por qualquer outro, que pode verbalizá-lo em meu lugar e agir para promovê-lo, minha identidade só torna-se visível por meio de um igual. Ela aproxima-se da "vontade" que, dizia Rousseau em sua defesa da participação direta, não se transmite a outro (ROUSSEAU, 1964, p. 368). A identidade tampouco. Eu posso não estar presente no grupo de governantes, mas minha identidade estará lá não por meio de um representante e sim corporificada em alguém que a possui em comum.

Em sua obra posterior, porém, Phillips vai cada vez mais falar de perspectiva social em lugar de identidade. Menos fechado e com caráter mais relacional, o conceito de perspectiva social é capaz de cumprir a mesma função que a identidade - o não-representável que exige a presença política - escapando às suas dificuldades, sobretudo a um essencialismo em potencial. Ele vai ser mobilizado para justificar de forma mais sofisticada as demandas por presença, fugindo tanto da concepção de que as mulheres possuem uma sensibilidade diferenciada que as credenciaria à posição de vetores de uma política mais altruísta e humana quanto da visão de que elas precisam ocupar espaços de poder para defender seus interesses específicos, que levaria à questão espinhosa: quem define quais são os interesses das mulheres? (MIGUEL, 2001).

O conceito de perspectiva social vai ganhar curso a partir, sobretudo, da obra de Iris Marion Young. A discussão adquire centralidade em Inclusion and Democracy (YOUNG, 2000), exatamente o livro em que ela dedica-se a reunir e sistematizar sua reflexão sobre os problemas da representação política. Mas liga-se estreitamente à polêmica sobre o ideal da imparcialidade, que estrutura Justice and the Politics of Difference (YOUNG, 1990a), e também seus textos dos anos 1970 e 1980 sobre corpo e experiência vivida, que foram reunidos na última seção de "Throwing Like a Girl" (YOUNG, 1990b) e depois republicados, ao lado de trabalhos posteriores com enfoque similar, em On Female Body Experience (YOUNG, 2005).

$\mathrm{Na}$ formulação mais sintética e operacionalizável, perspectiva social é definida como "o ponto de vista que membros de um grupo têm sobre processos sociais por causa de sua posição neles" (YOUNG, 2000, p. 137). A principal vantagem do recurso ao conceito, no entendimento da própria autora, é que ele captaria a sensibilidade da experiência gerada pela posição de grupo, sem postular um conteúdo unificado - é um ponto de partida, não de chegada. 
A representação política, então, englobaria três facetas - interesse, opinião e perspectiva (idem, p. 134-136). Não se trata de negar a legitimidade da busca da satisfação de interesses, entendidos como instrumentos para a realização de fins individuais ou coletivos, por meio da ação política, nem de descartar as opções políticas baseadas em opiniões, isto é, nos princípios e valores que fundam o juízo, correspondendo em linhas gerais à "política de idéias" de Phillips. Estas duas facetas, porém, estariam bem incorporadas nas compreensões correntes sobre a representação política. $\mathrm{O}$ esforço seria acrescentar a terceira faceta, a das perspectivas, que engendra a exigência de presença.

Creio que a produção do conceito de perspectiva social atravessa três conjuntos de problemas. Primeiro, o entendimento do que constitui um grupo social. Em seguida, o valor ou ausência de valor da imparcialidade como critério de justiça. Por fim, a relação entre experiência vivida e pensamento. As respostas que Young apresenta aos dois primeiros problemas são mais sólidas que aquelas dadas ao terceiro, que é a fonte de parte das dificuldades surgidas na utilização do conceito.

Young assinala que a filosofia política, em geral, não é apta de lidar com a noção de grupo social, incapacidade que ela atribui à visão individualista dominante. Quando um "grupo" aparece na filosofia política, ou bem é sob a forma de um conjunto de indivíduos que compartilham de uma característica comum identificada pelo observador externo (o grupo dos maiores de 65 anos, o grupo dos que vivem com menos de um dólar por dia, o grupo dos que têm olhos castanhos), ou bem é como uma reunião de indivíduos que decidem agir em defesa de um interesse comum. Nos termos da autora, são agregados ou associações (YOUNG, 1990a, p. 43). Ambos entendimentos são insensíveis ao caráter constitutivo do grupo, que é o aspecto relevante para Young.

Um grupo social, diz ela, é definido em primeiro lugar "não por um conjunto de atributos compartilhados, mas por um sentido de identidade" (idem, p. 44) ${ }^{7}$. Não é um agregado, formado por indivíduos reunidos por alguma classificação

\footnotetext{
7 Embora Young não faça essa discussão, há aproximações entre sua definição de "grupo social" e aquilo que Rousseau chama de "associação" - termo que, na obra dele, não designa, como na obra dela, uma reunião voluntária, conscien-
}

menos ou mais arbitrária, nem uma associação, cujos integrantes possuem selves e interesses constituídos de forma independente de seu pertencimento a ela: as pessoas formam associações, mas os grupos constituem os indivíduos (idem, p. 44-45). A pluralidade de grupos sociais é formadora, assim, da pluralidade de visões de mundo, de valores, de concepções do bem que caracteriza as sociedades contemporâneas.

Young vê esta pluralidade, assim como a diferenciação de grupos da qual ela brota, como sendo intrinsecamente desejáveis. Numa démarche comum ao pensamento radical do século $\mathrm{XX}$, o ideal de uma igualdade homogeneizante é substituído pela valorização das múltiplas diferenças identitárias. Ainda que mereça atenção o juízo de Nancy Fraser sobre o que chama de "versão indiferenciada e acrítica da política da diferença" (FRASER, 1997, p. 190), que não distingue entre diferenças nefastas, que devem ser abolidas (como a diferença de classe), e diferenças que expressam a diversidade humana e devem ser afirmadas, o movimento de uma visão niveladora para uma visão complexa da igualdade é bem sustentado. Tal movimento liga-se, no pensamento de Young, a uma fundamentada crítica ao ideal de imparcialidade, que tem como pano de fundo a discussão gerada pela teoria da justiça de John Rawls.

Buscando delinear os princípios de uma ordem social justa, princípios que seriam "onicompreensivos" e dotados de validade geral, Rawls conclui que eles só podem surgir caso os interesses vinculados às situações sociais distintas sejam deixados de lado - os interesses nublam o exercício da razão, como afirma uma extensa tradição do pensamento político, e a meta rawlsiana é a fundamentação racional da justiça. Ele chega, então, ao artifício da "posição original", sua releitura do estado de natureza dos contratualistas modernos: uma situação imaginária, onde ninguém soubesse quais seriam suas próprias condições, características pessoais ou preferências (RAWLS, 1997). Despidos de quaisquer interesses particulares, os habitantes da po-

te e auto-interessada, e sim um conjunto de relações capaz de transformar as identidades pessoais e gerar um sentimento de bem comum que transcende o individualismo (ROUSSEAU, 1964, p. 359). 
sição original seriam meras encarnações de uma razão universal, comum a todos os seres humanos. Apenas assim estariam em condições de pactuar uma ordem justa, que não oferecesse privilégios ou desvantagens a qualquer indivíduo.

Desta forma, na teoria de Rawls, a imparcialidade, que nasce da ausência de posição social, é uma condição necessária (e, ao lado da razão, suficiente) para a construção de uma compreensão válida e universalizável da justiça. Entre os muitos debates que "Uma teoria da justiça" provoca na filosofia política, os mais importantes questionam a noção de indivíduo abstrato, "desencaixado" de suas características distintivas, subjacente à idéia de posição original ${ }^{8}$. Em sua obra posterior, Rawls mostra-se sensível a parte das críticas, mas não o suficiente para abandonar o ideal da razão pública imparcial (RAWLS, 2000). E Young, que faz a crítica mais contundente à noção de imparcialidade, não está entre os autores com os quais Rawls estabelece uma interlocução expressa.

Em Justice and the Politics of Difference, Young começa ressituando o debate, passando da abstração dos princípios gerais para uma constatação situada historicamente: "justiça social significa a eliminação da dominação e opressão institucionalizadas" (YOUNG, 1990a, p. 15). Longe de ser um deslocamento banal, ela indica que, da mesma forma como os atores são socialmente situados, o debate sobre justiça é social e historicamente situado. São estes os desafios que a filosofia política deve enfrentar - e que a obra de Rawls não consegue responder.

O ideal da imparcialidade é enganoso, na medida em que não existe o ponto 'arquimediano' que nos permitiria escapar de nossas perspectivas socialmente situadas. O que é possível, isto sim, é que uma determinada perspectiva ganhe curso como sendo não-situada: a ilusão da imparcialidade é a imposição de um ponto de vista dominante, que aparece diante dos outros como sendo neutro, desvinculado de interesses e valores (idem, p. 97). Há, aqui, um poderoso mecanismo de reprodução das relações de dominação, que, ao negar o caráter situado dos discursos do-

8 Crítica central dos "teóricos da diferença", corrente na qual é possível situar Young, mas também, de outra forma, dos chamados "comunitaristas" (cf. SANDEL, 1998). minantes, faz deles porta-vozes do interesse universal, em contraposição aos interesses necessariamente parciais dos outros. É assim que só as mulheres têm sexo, só os negros têm cor, só os trabalhadores pertencem a uma classe social, só os gays têm orientação sexual. Ou, para usar exemplos mais concretos, na política de classes os partidos operários viam-se constrangidos a apresentar seu compromisso com um segmento específico, ao passo que os partidos burgueses não se anunciavam como tais, mas como defensores do interesse nacional, isto é, geral (cf. PRZEWORSKI, 1985). E os opositores das ações afirmativas não se manifestam como defensores da manutenção do acesso privilegiado de determinados grupos a determinados espaços (a universidade para os brancos, a política para os homens) e sim em nome da meritocracia "neutra" .

Ignorar os pertencimentos de grupo, como o ideal da imparcialidade propõe, prejudica aqueles que possuem experiências diferentes dos grupos privilegiados e estigmatiza os que se desviam do padrão considerado geral, ao mesmo tempo em que permite que os privilegiados ignorem ou não tematizem sua própria especificidade (YOUNG, 1990a, p. 164-165). Por outro lado, a visão de Rawls, baseada em uma hipóstase da Razão de fundo kantiano, leva a uma "deliberação" que é, no final das contas, monológica, já que os diferentes indivíduos, desprovidos de suas características definidoras, não passam de replicações da mesma racionalidade. "A idéia do tomador de decisão imparcial funciona, em nossa sociedade, para legitimar uma estrutura decisória antidemocrática e autoritária" (idem, p. 112). De fato, o debate pressupõe uma multiplicidade de interesses, de valores, de vivências - tudo aquilo que Rawls julga necessário abolir para alcançar a imparcialidade. Um único legislador e juiz imparcial seria capaz de produzir as decisões justas, sem necessidade de interação com outros.

A crítica à imparcialidade, como apresentada em Justice and the Politics of Difference, é o momento de maior radicalidade no pensamento

9 No romance "2666", do chileno Roberto Bolaño, um repórter explica a seu colega que, na sua redação, todos os profissionais são afro-americanos - e o outro questiona, “isso é bom para o jornalismo objetivo?" (BOLAÑO, 2009, p. 354). De fato, jornalistas brancos não contaminariam seu ofício com uma perspectiva parcial, branca, porque se entende que eles não a têm. 
de Young. Deslocando-se para o terreno da representação política, ela afirma que a especificidade de cada grupo exige que cada um adquira um determinado conjunto de direitos - e que uma democracia que reconheça os grupos deve promover ativamente formas de auto-organização dos membros do grupo, para que reflitam sobre suas experiências e interesses; dar a eles formas especiais de acesso aos tomadores de decisão; e mesmo garantir poder de veto em políticas que afetem diretamente o grupo (idem, p. 183-184). São propostas das quais ela recua posteriormente, sobretudo em Inclusion and Democracy, obra marcada por sua maior aproximação com uma vertente da teoria democrática - o deliberacionismo habermasiano - que, se não adere à ilusão da imparcialidade, adota como ideal um consenso que é a transcendência das parcialidades.

\section{PERSPECTIVA, HABITUS E ESTRUTURA DO CAMPO}

Assim, Young fundamenta a relação entre grupo social e identidade, e também justifica sua oposição à imparcialidade. Mas o conceito de perspectiva social pressupõe também uma relação entre experiência e pensamento, que Young está longe de explicitar, mas que pode ser rastreada em seus textos mais tributários do feminismo de Simone de Beauvoir e, tal como ele, da fenomenologia de Maurice Merleau-Ponty.

O recurso à noção de perspectiva só faz sentido se julgamos que a experiência vivida engendra uma visão de mundo, uma premissa razoável, mas que gera uma questão: como isso ocorre? Não é uma relação mecânica, nem toma a forma de uma determinação simples; ao contrário, existem mediações a serem levadas em conta. Não se trata de dizer que os interesses nascem das condições sociais objetivas, já que Young recusa expressamente tal leitura (e perspectiva aparece precisamente como alternativa, ou melhor, complemento à noção de interesse). Tampouco é possível dizer que é o "ser social que [...] determina a consciência" (MARX, 1983, p. 24), pois as perspectivas aparecem como uma forma aberta de ver o mundo, marcada pela sensibilidade especial para certos fenômenos ou aspectos de fenômenos, escapando ao discurso estruturado e fechado que é a ideologia.

As pistas que permitem entender qual resposta Young articulava ao problema estão em seus textos sobre o "corpo vivido" (lived body), em que ela desenvolve a idéia de que as expectativas sociais generalizadas conformam minha posição no mundo e impõem-me uma forma de relacionar-me com esse mundo que é própria do grupo ao qual pertenço. No decepcionante capítulo sobre a hexis corporal feminina, Young afirma que a mobilidade e espacialidade das mulheres é moldada pela tensão entre transcendência e imanência que é própria da sua experiência numa sociedade patriarcal, em que a mulher é tanto sujeito quanto objeto (YOUNG, 2005, p. 32). O argumento, inspirado em Beauvoir (2009), é forte o suficiente para nocautear seu adversário ostensivo, a tese de que, sem ser fruto da fisiologia nem da cultura, o modo da mulher mover e situar seu corpo seria a expressão de uma "essência feminina" de caráter metafísico. Derrotado o oponente, aliás não muito notável, o raciocínio revela-se de pouca valia.

Primeiro, porque a tensão entre imanência e transcendência pode ser identificada também na figura do trabalhador numa sociedade de classes, e nem por isso a hexis corporal de um operário homem será similar à feminina - ao contrário, é Young quem ressalva que sua argumentação sobre as mulheres não vale, por exemplo, para aquelas que desempenham trabalho braçal pesado. Depois, porque se avança muito pouco no passo seguinte (ou reverso da moeda): de que maneira essa hexis corporal específica, estruturada socialmente, estrutura ela própria, por sua vez, as vivências das mulheres no mundo. O mesmo vale para as discussões em que ela incorpora o tema da "heterossexualidade normativa", em que o foco está muito mais na percepção de que as regras de comportamento impostas limitam as experiências permitidas do que na relação entre as vivências e a produção de uma dada sensibilidade e um dado conhecimento sobre o mundo social (YOUNG, 1990 a, p. 24-25) ${ }^{10}$. Se ficarmos por aqui, a perspectiva é a incompletude, é somente o fruto das relações de dominação e do cerceamento da interação com o mundo, sem guardar nada da-

\footnotetext{
10 A abordagem é diferente naqueles textos em que trabalha momentos específicos da corporalidade da mulher, como gravidez, aleitamento e menstruação (Pregnant embodiment, Breasted Experience, Menstrual Meditations, todos incluídos em Young (1990a)), quando a vinculação entre vivência e formação de uma sensibilidade distinta coloca-se de forma mais clara. Mas está longe de seu projeto a idéia de uma pluralidade de perspectivas ancorada, em última análise, na biologia.
} 
quele caráter de pluralidade fecunda a ser festejada e estimulada. O ideal de Rawls seria o nosso ideal, apenas lamentaríamos o fato dele ser inalcançável.

Como não é assim, não para Young, o mecanismo de geração da perspectiva permanece dentro de uma caixa preta. Há uma série de experiências, de vivências, associadas a posições sociais e inacessíveis enquanto tais aos outros, por mais empatia e solidariedade que sintam ${ }^{11}$. Mas como isso gera uma visão distinta do mundo social é uma lacuna que, ao não ser preenchida, abre espaço para o mero senso comum, na forma de uma epistemologia empirista vulgar. No texto em que trata com mais cuidado da questão dos corpos vividos, Young não dedica mais do que dois parágrafos ao problema, não sem antes alertar que não teria espaço para desenvolver uma resposta satisfatória. Após afirmar que a estruturas de gênero condicionam e precedem a ação e a consciência das pessoas e que cada indivíduo vai lidar de sua própria forma com o conjunto constrangido de possibilidades que encontra (idem, p. 25), uma afirmação que, imagino, valeria para outras clivagens sociais, ela descarta o conceito bourdieuano de habitus. Considera-o excessivamente rígido e anistórico, "especialmente em seu entendimento das estruturas de gênero" (idem, p. 26), sendo preferível uma abordagem baseada nos corpos vividos de Merleau-Ponty, mas que a conectasse com as estruturas sociais.

Mas a precária sensibilidade de Bourdieu às complexidades das questões de gênero, demonstrada em La domination masculine, não seria razão para descartar o conceito de habitus, que creio ser muito mais flexível e sensível às dinâmicas sociais do que a fenomenologia preferida por Young. O ponto central, porém, não é esse. Entender habitus e perspectiva como conceitos concorrentes em relação aos quais há que se optar (ou, no máximo, que precisam ser fundidos) não

\footnotetext{
11 Para usar outro exemplo extraído da literatura: ao narrar a volta para casa de uma operária, no primeiro capítulo do romance $A$ filha do coveiro, Joyce Carol Oates mobiliza uma série de questões - vinculadas à posição subalterna no local de trabalho, à responsabilidade com a criação do filho, ao temor da violência sexual - que se expressam em suas idéias, em seu olhar sobre o ambiente, em sua postura corporal e que remetem a experiências próprias de uma mulher numa sociedade patriarcal, que um homem só é capaz de conhecer de fora (OATES, 2008).
}

é um ganho. Melhor é mantê-los como conceitos paralelos, capazes de vincular as formas de conhecimento do mundo e disposições para ação tanto aos efeitos estruturantes dos campos específicos quanto a posições na estrutura social em geral. Isso é que pode abrir caminho para entender, por exemplo, as mulheres na política, levando em conta os dois substantivos da expressão. Estão na politica, ou seja, num campo social que exige daqueles que nele ingressam adequação a certo habitus, mas são mulheres, portadoras de uma perspectiva social minoritária naquele campo e específica na estrutura social.

Ainda que o conceito de perspectiva, tal como desenvolvido por Young, guarde essa lacuna, relativa à relação entre experiência e pensamento, que traz implicações na forma de sua apropriação para entender-se a presença política, ele permanece como uma ferramenta útil, capaz de contribuir para a análise quer no plano descritivo, quer no normativo. Mas há dois pontos adicionais que devem ser levados em consideração. Primeiro, o que julgo ser uma insuficiência na visão de Young sobre representação. Em seguida, sua adesão, por vezes pouco crítica, a um ideal - a deliberação habermasiana - que compromete as virtualidades emancipacionistas de seu empreendimento teórico.

A percepção de que as experiências vividas estruturam perspectivas que, então, devem-se fazer ouvidas nos espaços de poder, leva Young - e aqueles que partem de sua reflexão - a desconsiderar ou, no máximo, deixar em segundo plano o caráter constitutivo da representação política $^{12}$. Algo que já é colocado para reflexão por Hobbes, que, numa passagem crucial do Leviatã, afirma ser a presença do representante que gera a comunidade política, não o contrário. Onde não há um porta-voz autorizado, no qual o grupo reconheça-se, permanece apenas um conjunto de indivíduos atomizados (HOBBES, 1997, p. 137).

Um dos sentidos de "representar" é reduzir uma realidade a algo que lhe é exterior, preservando suas características essenciais e descartando

12 Ela aborda brevemente a questão (YOUNG, 2000, p. 130), mas deixa-a em posição periférica no conjunto de seu pensamento. Neste parágrafo e nos próximos, sintetizo e adapto uma discussão presente em texto anterior (MIGUEL, 2009). 
outras, secundárias. Mas a fixação do que é essencial e do que não é, longe de ser objetiva, implica em escolhas sujeitas a divergências. Ao estabelecer-se, a representação constitui o grupo, determinando em que consiste seu cerne. Ela cumpre, assim, uma função produtiva: "Se a sociedade é apreendida como estando composta de unidades elementares discerníveis, a representação consiste numa simples descrição, em uma tradução. Mas se a sociedade é considerada, ao contrário, como opaca e ilegível, a representação deverá tomar uma dimensão construtiva: para exprimir a sociedade, ela deve antes produzi-la" (ROSANVALLON, 1998, p. 119).

Esta dimensão construtiva não é arbitrária. Ela deve respeitar um conjunto de possibilidades que é dado pelo próprio tecido social. Por isso, mudanças nos padrões identitários geram desafios à representação política, sobretudo quando as novas identidades parecem não se fazer representar com facilidade. Rosanvallon observa que "a menor visibilidade dos sistemas de diferenciação em nossas sociedades [...] contribuiu, em seu conjunto, para fazer o sistema representativo entrar em sua nova crise" (idem, p. 417). Ele julga que as clivagens sociais diluíram-se, fruto de um processo material de homogeneização, visão que me parece insustentável. É mais interessante pensar em termos de padrões de identidade sobrepostos, de forma que um grupo social não pode mais agir como se esgotasse os pertencimentos coletivos de seus integrantes.

Young não é insensível a esse problema, mas, quando o aborda, coloca-o à parte, dissociando-o por completo de sua discussão sobre representação de grupos sociais. Ao questionar se é legítimo caracterizar as mulheres como grupo social específico, o que se justificaria pelo fato de que existem constrangimentos estruturais que afetam todo o gênero feminino, ela debate-se com o problema de que o coletivo "mulheres" engloba vivências e perspectivas sociais muito díspares. Sua resposta é recorrer ao conceito de "serialidade", extraído da obra de Sartre. As mulheres não formariam um grupo, mas uma série, formulação que preservaria a heterogeneidade de suas posições - mas que é contraditória em relação à sua obra anterior e fincada numa concepção muito mais restritiva de grupos, "coletivos autoconscientes que se reconhecem mutuamente como tendo propósitos comuns ou experiências compartilhadas" (YOUNG, 1997, p. 34).
Não é uma solução convincente, já que, tomada em sua formulação original, a concepção sartreana de "serialidade" exclui a percepção de uma identidade (ainda que imperfeitamente) compartilhada - importante no caso de gênero, segundo Young mesma afirma em outros momentos. Creio que parte do problema advém da compreensão subjacente de que a identidade de grupo simplesmente brotaria da experiência comum, que é o reverso da negação do caráter constitutivo da representação.

O ponto final que desejo enfocar neste sobrevôo pelo conceito de perspectiva é o ideal para o qual ele parece apontar, em muitas de suas utilizações, incluídas aí as da própria Young. A tarefa do momento seria abrir as portas do debate público para as múltiplas vozes, dar presença às perspectivas hoje ausentes dos espaços decisórios. Feito isso, o resultado seria uma espécie de polifonia, para a qual todos os grupos contribuiriam. A inclusão, por si só, geraria a legitimidade das decisões e a justiça.

Trata-se de uma versão multiculturalista do ideal da esfera pública discursiva de Habermas e seus epígonos da vertente democrática deliberativa. A relação de Young com o modelo habermasiano não é isenta de oscilações. Em "Justice and the Politics of Difference", ela afirma expressamente seu endosso crítico à "concepção geral de justiça derivada de uma concepção de ética comunicativa" (YOUNG, 1990a, p. 34), com o adjetivo "crítico" correspondendo à sua oposição ao universalismo kantiano que contamina a obra de Habermas (idem, p. 118). Em "Inclusion and Democracy", a crítica está bem atenuada e ela situa-se firmemente no campo da democracia deliberativa, com seus critérios normativos sobre o tipo de discurso aceitável para o debate - apenas aquele em que há a transformação de preferências privadas em apelos públicos por justiça (YOUNG, 2000, p. 51), embora ela mostre-se generosa ao ponto de permitir que, secundariamente ao argumento racional, sejam incluídas a saudação, a retórica e o testemunho (idem, p. 79). Mas em artigo pouco posterior ela apresenta uma crítica aprofundada das mazelas da deliberação, observando como ela é distorcida pela existência de um discurso hegemônico e, em muitos casos, conservadora (YOUNG, 2001).

De maneira muito esquemática, a democracia deliberativa prega que as decisões políticas tor- 
nam-se justas quando são o fruto do debate público, racional e livre entre iguais. Trata-se de um ideal bastante exigente, que prevê que a discussão estará franqueada a todos, em igualdade de condições, isto é, a única distinção aceitável entre os participantes é aquela ligada à qualidade dos argumentos apresentados. Estes argumentos, para serem expostos, devem satisfazer à condição de serem "racionais", portanto capazes de atingir os interlocutores no que todos temos em comum, a nossa racionalidade. Como a razão é compartilhada, é possível esperar o consenso como resultado do processo de deliberação.

Há muitos problemas associados à visão de democracia deliberativa, alguns dos quais são importantes para a discussão sobre perspectiva ${ }^{13}$. Num movimento similar ao do liberalismo, que estabelece a igualdade política formal a despeito das desigualdades materiais, o espaço público discursivo ideal seria capaz de deixar as assimetrias sociais "entre parênteses", relevando as diferenças de status, dinheiro e poder ao considerar apenas a força dos argumentos racionais. Além de, uma vez mais, desconectar a política do restante do mundo social, esta posição não consegue abordar as condições de emissão do discurso aceitável - o que faz alguns grupos serem dotados da capacidade de produzir "argumentos racionais" e outros, não. O discurso argumentativo racional não é uma mera derivação da racionalidade humana, mas um modelo específico, com suas próprias regras, constituído historicamente. O consenso, que idealmente é o resultado das trocas discursivas de razões, pode sinalizar apenas a incapacidade que alguns grupos têm de formatar seus interesses em termos adequados. Exilados do debate efetivo, não restaria a eles outra opção que não abraçar "preferências adaptativas" (SUNSTEIN, 2009), com o consenso recobrindo não a livre e igual aceitação de todos, mas uma forma disfarçada de permanência da dominação.

A democracia deliberativa também encontra dificuldades para lidar com a representação política. O modelo habermasiano é inspirado na comunicação face a face, em que cada indivíduo fala apenas por si mesmo. Boa parte da corrente trabalha num elevado grau de abstração, que permite

13 Para uma discussão mais aprofundada, ver Miguel (2002). ignorar os problemas que se colocam quando o ideal é transportado para uma sociedade populosa complexa. Outros optam por focar a deliberação em espaços de poder, como parlamentos ou cortes de justiça, sem questionar como seus integrantes relacionam-se com o demos. Uma terceira alternativa, enfim, é evidenciar os processos de discussão presentes na sociedade, mas deixando em aberto sua relação com as decisões políticas ou, então, inserindo-a num modelo de influência difusa da opinião pública sobre os decisores, sobretudo por meio das eleições, que pouco difere da narrativa liberal padrão, como é o caso da obra madura do próprio Habermas (1997).

Sobretudo em Inclusion and Democracy, Young apresenta o pleito pela incorporação das perspectivas marginalizadas como um aprimoramento da democracia deliberativa. Assim, ela vê as diferentes perspectivas como formas de um "conhecimento social" associado à experiência vivida, que precisam ser incluídas no debate a fim de melhorar a qualidade da deliberação (YOUNG, 2000, p. 136). Em outro trecho, as restrições que os democratas deliberativos aplicam aos discursos, a fim de que sejam considerados dignos de ingressar na conversação pública, são expressamente endossadas: "A inclusão não deve significar simplesmente a igualdade formal e abstrata entre todos os membros de um público de cidadãos. Ela significa considerar explicitamente as divisões e diferenciações sociais e encorajar grupos diversamente situados a dar voz a suas necessidades, interesses e perspectivas sobre a sociedade, de maneira que correspondam a condições de publicidade e razoabilidade" (idem, p. 119).

Ora, os imperativos de publicidade e razoabilidade são, aqui, implicitamente admitidos como universais; suas determinações concretas, para obter tal validade e não incorrer na acusação de favorecer algum grupo social em detrimento de outros, devem necessariamente partir de uma posição não-situada socialmente. Trata-se de um evidente retrocesso em relação a Justice and the Politics of Difference. Sem os conceitos de dominação e opressão, que eram centrais naquela obra, mas empalidecem depois, a radicalidade da posição de Young torna-se invertebrada. A urgência da incorporação das vozes subalternas é afirmada com convicção e há o reconhecimento, mais claro que em outros habermasianos, do caráter conflituoso da política (idem, p. 44), mas tal con- 
flito perde o sentido moral e torna-se, ao mesmo tempo, sanável pela força do argumento racional, agora ladeado por saudação, retórica e testemunho, formas discursivas menores, mas que os grupos desprivilegiados talvez manejem melhor.

A ênfase nas vantagens cognitivas das múltiplas perspectivas tende a ofuscar o problema dos conflitos de interesses. Surge aqui outra questão importante, a vinculação entre as perspectivas e os interesses. Young tende a isolar perspectivas de interesses, o que ocorre em parte devido à estratégia de exposição de sua teoria, em parte por influência do ideal deliberativo, que julga que todos os participantes do debate devem estar prontos a mudar de posição diante de argumentos superiores, o que limita o espaço de defesa de interesses (idem, p. 139-140). Mas não é possível desvincular interesses e perspectivas, exceto como artifício heurístico - ou teríamos que descartar a idéia de que há um nexo entre as posições na estrutura social e a produção dos interesses (v. WILLIAMS, 1998, p. 171; MIGUEL, 2003, p. 129-130). Enfim, a presença de múltiplas perspectivas sociais no debate público pode, sim, ser vantajosa para ampliar sua qualidade epistêmica, mas não é razoável deixar de lado o fato de que ela, sem postular qualquer derivação mecânica ou determinista, amplia a possibilidade de que os interesses dos grupos dominados se façam representar.

Fica claro que a crítica imperfeita ou interrompida de Young a Habermas é o principal limite de sua empreitada teórica. A noção de que a luta por justiça significa o enfrentamento dos padrões historicamente constituídos de opressão e dominação recua diante da visão procedimental, que faz a norma justa ser o fruto, qualquer fruto, da deliberação levada a cabo de maneira "adequada". O próprio efeito das injustiças sociais no processo deliberativo é anulado pelo fetichismo do "argumento racional”, que permanece lá, a despeito dos adendos que Young apõe a ele. Enfim, a acomodação com os preceitos habermasianos leva-a a oscilar em seu compromisso, próprio de uma intelectual crítica, com uma percepção substantiva do que é a boa sociedade, a justiça e a igualdade.

É realmente uma oscilação. Em “Activist Challenges to Deliberative Democracy”, publicado apenas um ano após Inclusion and Democracy, ela constrói o diálogo hipotético entre uma deliberacionista e um ativista; este último vocaliza a urgência das transformações sociais, vendo o processo deliberativo como sendo protelatório, potencialmente conservador, legitimador do statu quo e enviesado pelas desigualdades já existentes. Embora conclua pela necessidade de afirmar tanto o deliberacionismo quanto o ativismo, reconhecendo as tensões entre ambos, Young admite a questão central, que a existência de uma dada hegemonia distorce a deliberação (YOUNG, 2001, p. 685-686), rompendo com o ponto cego do idealismo habermasiano. Aqui, ao que parece, a incorporação das perspectivas dos grupos marginalizados ao debate público não é mais um ponto de chegada, uma solução para o problema da justiça. Seria antes um ponto de partida para a luta contra dominação e opressão.

O conceito de "campo político", extraído da obra de Pierre Bourdieu, é uma ferramenta útil que permite problematizar algumas das lacunas deixadas por Young. Campo, na terminologia do sociólogo francês, designa uma configuração de relações objetivas entre posições de agentes ou de instituições. Esta configuração constitui o campo, ao mesmo tempo em que é constituída por ele. Os diferentes campos sociais formam-se à medida que determinadas práticas geram um espaço de autonomia. Assim, a formação de um campo artístico ou literário, por exemplo, permitiu que a arte ou a literatura - até certo ponto - regulassem a si mesmas (BOURDIEU, 1998b). Muito concretamente, fez que as modalidades de consagração dependessem das relações estabelecidas no próprio campo e não mais fossem impostas de fora, pelo dinheiro ou pelo Estado.

Desta forma, os campos são as estruturas objetivas, que impõem sua lógica aos agentes que deles participam - a busca do lucro, no campo econômico; do reconhecimento pelos pares, no campo artístico etc. Cada campo gera uma prática específica e também uma espécie de capital, isto é, uma forma de valor que só se estabelece enquanto tal porque é socialmente reconhecida. Portanto, campo e habitus são conceitos complementares. O habitus é o campo interiorizado, ao mesmo tempo em que são as práticas dos agentes, conformadas pelo habitus, que propiciam a reprodução das estruturas do campo. Justamente por isso, o efeito de doxa, a adesão imediata entre as minhas categorias mentais e aquilo que apreendo como sendo a realidade, é possível. 
O conceito de "campo político", em particular, permite entender que a disputa política não se esgota nos locais institucionalizados de tomada de decisão - eleições, parlamentos, partidos, governos. Mas também evita o "tudo é política" que retira dela qualquer especificidade, tornando-a coextensiva à própria sociedade. $\mathrm{O}$ espaço da política não é dado: é construído historicamente e moldado e remoldado de acordo com os embates entre os agentes. Tampouco é um espaço oco. É um campo estruturado, com sua hierarquia de influência, que privilegia certas posições e barra a entrada de grupos estranhos.

O campo político é, segundo a definição de Bourdieu, "o lugar em que se geram, na concorrência entre os agentes que nele se acham envolvidos, produtos políticos, problemas, programas, análises, comentários, conceitos, acontecimentos, entre os quais os cidadãos comuns, reduzidos ao estatuto de 'consumidores', devem escolher" (BOURDIEU, 1989, p. 164). Todo campo definese pela imposição de critérios próprios de avaliação da realidade, em especial pela fixação de objetivos que se apresentam como "naturais" para aqueles que deles participam - neste caso, a busca pelo poder político.

Assim, o campo seria "um universo obedecendo a suas próprias leis" (BOURDIEU, 2000, p. 52), expressão que sintetiza a autonomia, que todo campo almeja, e o fechamento sobre si próprio, que caracteriza a todos. No entanto, o fechamento encontra limites, muito claros no caso da política, que periodicamente precisa abrir-se para os simples eleitores. O importante é observar que as posições no campo político não são mero reflexo das votações recebidas; basta lembrar de tantos campeões de voto, sejam eles radialistas, cantores ou esportistas, que ocupam um lugar menos do que secundário no Congresso. $\mathrm{O}$ capital político é uma forma de capital simbólico, dependente do reconhecimento fornecido pelos próprios pares. Como todos, em certos momentos-chave, lutam por votos, a popularidade contribui para tal reconhecimento, mas não é o único determinante.

O campo exclui, na medida em que estabelece um dentro e um fora. É mais do que ter ou não ter acesso aos espaços formais de tomada de decisão (no caso da política); é a distância entre aqueles que são socialmente considerados como capazes de intervir no debate político e a massa dos que devem abster-se de tentar participar, porque eventuais tentativas não serão mesmo levadas a sério. E o campo exige adaptação a seus códigos, às suas regras, em suma, ao habitus que lhe é próprio: "o habitus do político supõe uma preparação especial. É, em primeiro lugar, toda a aprendizagem necessária para adquirir o corpus de saberes específicos (teorias, problemáticas, conceitos, tradições históricas, dados econômicos etc.) produzidos e acumulados pelo trabalho político dos profissionais do presente e do passado ou das capacidades mais gerais tais como o domínio de uma certa linguagem e de uma certa retórica política, a do tribuno, indispensável nas relações com os profanos, ou a do debater, necessária nas relações entre os profissionais. Mas é também e sobretudo esta espécie de iniciação, com as suas provas e os seus ritos de passagem, que tendem a inculcar o domínio prático da lógica imanente do campo político e a impor uma submissão de fato aos valores, às hierarquias e às censuras inerentes a este campo (BOURDIEU, 1989, p. 169-170; ênfases suprimidas).

A incorporação de perspectivas diferentes, tal como preconizada por Young e outros teóricos da diferença, encontra limites no fato de que o campo político exige a acomodação das variadas trajetórias e posições sociais à sua própria lógica. Esta incorporação pode ser conflituosa, mas isso não elimina a tendência à reprodução das hierarquias de acordo com os critérios imperantes no campo. Por mais que, como o próprio Bourdieu indica, os integrantes do campo sejam capazes de agir de forma estratégica para reconfigurá-lo, buscando torná-lo mais favorável à sua própria posição e trajetória, uma pluralidade de perspectivas de origem sempre precisará lidar com a exigência uniformizadora da posse de um habitus adequado para a permanência naquele espaço. A concentração do capital político, própria dos regimes representativos, nos quais o poder de participar efetivamente das discussões e de tomar as decisões fica monopolizado por um grupo restrito de indivíduos, é em si mesma geradora de desigualdade.

Um mecanismo especialmente importante de exclusão do campo político é a exigência de adequação a um determinado padrão discursivo. $\mathrm{O}$ "discurso político espontâneo dos dominados", como diz Bourdieu, é desacreditado simbolicamente. Ele não corresponde aos critérios de elevação de vocabulário, de respeito à norma lingüística culta, de apresentação na forma de "argumentos 
racionais" que garantem a respeitabilidade necessária para que seja de fato ouvido no campo político. Mesmo elementos à primeira vista irrelevantes, como o sotaque ou o timbre de voz, contribuem, em situações de fala efetivas, para desqualificar os integrantes de grupos minoritários (BICKFORD, 1996, p. 97-98). Múltiplas instâncias, no coração do campo político ou à volta dele, como é o caso dos meios de comunicação de massa (MIGUEL \& BIROLI, 2008), reforçam este fechamento dos modos do discurso.

Aos grupos dominados, resta a opção entre insistir em sua dicção própria, gerando um discurso com pouca legitimidade no campo, portanto potencialmente menos efetivo, ou mimetizar os modos dominantes, traindo a experiência vivida que se desejava expressar e contribuindo para a reprodução das estruturas que excluem a eles próprios (BOURDIEU, 1979, p. 538). Esse dilema, que será analisado com mais vagar na seção seguinte, situa o limite da incorporação das vozes dominadas ao debate político. Não se trata de dizer que o subalterno não pode falar, uma vez que o silêncio está definido por sua própria subalternidade (SPIVAK, 1998), fórmula que sacrifica as complexidades do embate político concreto à elegância retórica. Mas entender que a fala do subalterno permanece uma fala subalterna, submetida a dilemas que as falas dominantes não precisam enfrentar.

O ideal habermasiano de consenso esclarecido é uma espécie de canto monódico; acrescentado da exigência de incorporação das múltiplas perspectivas sociais, torna-se a polifonia referida antes. Mas esta polifonia, enquanto resultado harmonioso da convivência entre diferentes melodias, também exigiria a compatibilização (embora não a uniformização) dos vários conhecimentos sociais situados, que se comunicam uns aos outros por meio do debate racional. Uma consciência mais aguda das limitações impostas pela estrutura do campo à presença dos discursos dominados permite entender que, antes de participantes do arranjo polifônico, a eles cabe o papel de ruído, de dissonância.

Perspectiva social (o fruto da posição ocupada na estrutura da sociedade) e habitus (as disposições para ação associadas aos campos) permanecem como conceitos em paralelo. Não tenho a pretensão de eliminar as tensões imanentes entre eles ou produzir um sistema capaz de incluir a ambos. Mas para a questão que aqui interessa - a presença de grupos dominados, mulheres em particular, no campo político -, ambos mostram-se úteis. De maneira ainda esquemática, como primeira aproximação, é possível dizer que o habitus tende a refletir perspectivas daqueles que se encontram em posição dominante no campo. O ruído que a incorporação de novas vozes gera tem relevância na medida em que pode desnaturalizar as perspectivas dominantes incorporadas no habitus, forçar seus limites e, assim, gerar mudanças.

\section{DESIGUALDADES E TRANSFORMAÇÃO}

É possível avançar na discussão relacionando-a à diferenciação que Nancy Fraser faz entre estratégias "afirmativas" e estratégias "transformadoras" (FRASER, 2003, p. 75). As primeiras têm por objetivo a incorporação de mais grupos aos espaços sociais de poder e status, questionando as hierarquias vigentes e modificando a composição dos seus estratos superiores, mas não colocando em xeque sua existência. Se uma determinada política garante o ingresso de mais negros nas universidades, reduz-se a desigualdade entre os grupos raciais e dilui-se a vinculação entre raça ou cor e determinadas posições no mercado de trabalho. Mas não é atingida a distinção entre aqueles que possuem um título do ensino superior, portanto acesso potencial a espaços sociais privilegiados, e aqueles que não o possuem; nem se questiona a validade de raça ou cor para adscrever um indivíduo em determinado grupo. O resultado, por assim dizer, não é a abolição da desigualdade social, mas sua "melhor distribuição" entre os diversos grupos.

O mesmo pode-se dizer das cotas eleitorais para mulheres. Elas não enfrentam o problema da concentração do poder decisório nos regimes representativos, o fato de que as pessoas comuns, embora nominalmente sejam coparticipantes da soberania, estão fadadas à situação de objetos da decisão política. Não enfrentam, para traduzir o problema nos termos assumidos na seção anterior, o fato de que o campo político gera a desigualdade política, excluindo os cidadãos comuns e hierarquizando suas próprias posições internas.

Já as estratégias transformadoras incorporariam uma ambição utópica. Elas teriam por objetivo "desconstruir" tanto as oposições binárias que fundam as identidades de grupo quanto as próprias estruturas da desigualdade social. Aplicando a distinção a outra dicotomia que estrutura seu pen- 
samento, redistribuição e reconhecimento, Fraser indica que, no caso da redistribuição, a estratégia afirmativa geral é o Estado de bem-estar, que não mexe nas relações de produção, mas mitiga seus efeitos iníquos, e a transformação é o socialismo (idem, p. 74). No caso do reconhecimento, as estratégias são o multiculturalismo, voltado a revalorizar identidades hoje estigmatizadas como inferiores ou desviantes (estratégia afirmativa), e a "desconstrução" das oposições simbólicas identitárias (estratégia transformadora) (idem, p. 75).

Conforme ela mesma aponta, a diferenciação proposta ecoa a velha polêmica, que marcou o movimento socialista do século passado, sobre reforma e revolução. Não interessa, aqui, discutir os limites deste paralelo, que só ganha maior relevância na medida em que a autora vai buscar na estratégia das "reformas não-reformistas", que ela vincula a interpretações à esquerda sobre a política social-democrata até meados do século XX, a resposta para o impasse que sua dicotomia abre: uma opção "realista" que pode promover mudanças efetivas, porém limitadas, e carrega em si um elemento conservador ou uma opção "utópica" com escassas possibilidades de efetivar-se. A estratégia das reformas não-reformistas, diz ela, "combina a praticabilidade da afirmação com o empuxo radical da transformação, que ataca as injustiças desde a raiz" (idem, p. 80).

É difícil ver nessa fórmula mais do que wishful thinking ou uma solução apenas retórica para um dilema real. O exemplo que Fraser elege é a proposta de renda básica universal, que garante a todos um rendimento assegurado pelo simples fato de ser um cidadão, independentemente de participar ou não do mercado de trabalho. Ela libertaria os trabalhadores da obrigação de vender sua força de trabalho em troca da subsistência, ao mesmo tempo em que manteria a economia de mercado e a propriedade privada. Um de seus principais difusores, o filósofo belga Philippe Van Parijs, chega a afirmar que a renda universal realizará o "velho ideal emancipatório associado ao movimento comunista, sem exigir para tanto nada semelhante a um modo socialista de produção" (VAN PARIJS, 1992, p. 466) ou mesmo que constitui "uma via capitalista para o comunismo" (VAN DER VEEN \& VAN PARIJS, 1987).

Mas a permanência da ordem capitalista impõe restrições às mudanças que a renda básica pode promover. Em nome de uma proposta mais radical, que dividiria de forma igualitária o trabalho e distribuiria o tempo livre, visto como o principal bem social, André Gorz aponta que a mera concessão deste salário-cidadão contribuiria para a atomização dos indivíduos, eliminando o espaço público associado às atividades produtivas, sem apresentar outro em troca (GORZ, 1991, p. 174). Mais importante ainda, a alocação universal "permite à sociedade não se ocupar da repartição equitativa do fardo" do trabalho (idem, p. 176). A sociedade seria cortada em duas, alguns permanecendo vinculados a um ethos aquisitivo, buscando maior retribuição monetária e, assim, maiores possibilidade de consumo, e outros eximindo-se de dar sua contribuição para o bem-estar coletivo. Em suma, o projeto desempenharia um papel conservador, visando apenas "tornar socialmente suportável a dominação [da racionalidade econômica] sobre a sociedade" (GORZ, 1988, p. 165) e negando a uma parcela da população o "direito de acesso à esfera econômica pública através do próprio trabalho [que] é indissociável do direito à cidadania" (idem, p. 175) $)^{14}$.

Fraser não ignora tais problemas, mas prefere julgar que o caráter meramente afirmativo da renda básica universal pode metamorfosear-se em transformador num regime social-democrata, alterando a relação de forças entre capital e trabalho e mesmo, combinado com estruturas públicas de atenção à criança, modificando a divisão sexual do trabalho (FRASER, 2003, p. 78-79). Há um salto argumentativo, em que se passa da noção de que políticas afirmativas podem ser apropriadas por estratégias transformadoras, que é o que Fraser de fato diz, à de que elas engendram, por sua própria dinâmica, processos de transformação, que é o que corresponde à idéia de "reformas não-reformistas" e que não transparece de seu exemplo.

Fazendo a discussão retornar ao campo político, a incorporação das perspectivas dominadas (estratégia afirmativa, nos termos de Fraser) sofre ainda com as exigências de adequação ao habitus imperante, conforme visto na seção anterior. Há um movimento, assim, de reprodução das estruturas já estabelecidas, que, se fosse inconteste,

14 Para uma discussão mais extensa da proposta de Gorz e de sua relação com o projeto de renda básica universal, ver Miguel (2006). 
tornaria inóxia a absorção de integrantes de outros grupos sociais.

Mas a presença política gera, sim, efeitos, na medida em que força os limites do campo político e do habitus a ele associado. Quanto mais distante o grupo está do campo - e quanto menos os integrantes deste grupo dominam os códigos discursivos considerados legítimos -, mais a exigência de incorporação encontra resistências e mais mudanças na estrutura do campo requer para ser atendida. Este é o valor do "ruído" que os grupos dominados introduzem no debate público. A reivindicação da pluralidade de perspectivas, assim, tensiona as formas estabelecidas de exclusão e dominação. Se não há um "ponto de chegada", uma situação ideal em que todas as perspectivas sociais estejam igualmente presentes, uma vez que o campo reinventa a cada momento os seus princípios de hierarquização, a consciência da exclusão pode forçar a redefinição permanente dos seus limites.

Em suma, a incorporação de perspectivas diferenciadas convive com a reprodução de concentração de poder que caracteriza esses campos, mas impõe novos desafios às formas como essa reprodução dá-se. A afirmação da pluralidade social ou a defesa da ampliação das perspectivas sociais presentes não encerra nenhuma panacéia, nem tem como resultado a polifonia imaginada por Young. Mas quanto mais radical for a exigência de inclusão, maior seu efeito potencial na reconfiguração das estruturas de desigualdade da política. Os diferentes atores sociais não são objetos passivos dos mecanismos de reprodução, mas participantes ativos de um "regime dinâmico de lutas contínuas por reconhecinento", para usar a expressão de Nancy Fraser (2003, p. 57), capazes de buscar uma nova conformação das relações de poder, mais convenientes para si próprios. Embora a obra de Bourdieu seja, com freqüência, lida como demasiado focada nas formas de perpetuação da dominação - e de fato esta é sua ênfase predominante -, ela é sensível também aos mecanismos de mudança. O campo e o habitus, portanto, enquadram os agentes sociais, mas também se modificam a partir de suas práticas.

Ainda assim, permanecemos no espaço das ações de caráter afirmativo. Elas tensionam os limites do campo, portanto não são irrelevantes. É verdade que não ameaçam a desigualdade política, mantendo a linha divisória entre os simples cidadãos e aqueles que têm oportunidade de intervir no debate público. Alternativas para reduzir a desigualdade política, como aquelas aventadas pelos defensores da democracia participativa das décadas de 1970 e 1980, dirigem-se a outro conjunto de questões. Elas referem-se antes às relações entre representantes e representados do que à composição do grupo de representantes.

A política de presença, porém, não se opõe, nem obstaculiza a adoção de medidas de caráter mais radicalmente igualitário. Antes, é possível ver ambas como complementares, até porque a composição do grupo de representantes possui reflexos na forma de sua interlocução com os constituintes. Isso não significa aderir à visão das "reformas não-reformistas", mas entender que ações afirmativas podem - ou não - ser combinadas com ações transformadoras; e que, a menos que se opte por um mergulho sem escalas na utopia, a política afirmativa pode manter sua relevância mesmo quando uma política transformadora é posta em prática. Trocando em miúdos: a defesa da política de presença não deve embaçar a consciência de que é necessário enfrentar de forma mais radical o problema da desigualdade política, mas como a remoção da representação não está no horizonte de possibilidades (e portanto há de permanecer alguma diferenciação funcional relativa às responsabilidades políticas), não podemos evitar o problema da pluralização dos grupos sociais presentes nos espaços de poder. E como esses espaços não serão ocos, mas estruturados na forma de campos, não é possível ignorar as maneiras pelas quais as hierarquias já estabelecidas trabalham para neutralizar as perspectivas potencialmente disruptivas.

Para entender melhor a tensão entre a incorporação de novas vozes e a sua manutenção em situação de subalternidade, desloco-me para exemplos extraídos do campo literário brasileiro. $\mathrm{O}$ paralelo com o campo político estabelece-se com facilidade: ambos são espaços que exigem o domínio de certa forma discursiva. Embora em princípio qualquer um possa fazer literatura ou fazer política, o reconhecimento de um discurso como literário ou como político passa pela adequação aos códigos consagrados no campo. E o campo da literatura brasileira mostra-se tão homogêneo quanto o da política. Tomando como base os romances publicados pelas editoras de maior prestígio entre 1990 e 2004, verifica-se que 93,9\% dos autores são brancos, 78,8\% têm diploma uni- 
versitário, 72,7\% são homens (DALCASTAGNÈ, 2005, p. 31). As personagens também são quase todas brancas, heterossexuais e pertencentes às elites econômicas ou às classes médias, com uma significativa maioria do sexo masculino, disparidades que se acentuam quando são isolados os protagonistas. Num universo de 258 romances analisados, aparecem apenas três mulheres negras como protagonistas e uma única é narradora (idem, p. 47). A literatura dos anos $1960 \mathrm{e}$ 1970 apresenta perfil muito semelhante (DALCASTAGNÈ, 2007; 2008).

Neste cenário, surgem, vez por outra, vozes diferenciadas. O caso mais emblemático é o de Carolina Maria de Jesus, negra, pobre, favelada, mãe solteira, catadora de papel, que é descoberta por um jornalista e tem publicado seu diário, "Quarto de despejo", em 1960. Embora ela construa para si mesma a imagem de escritora, de criadora, sua obra é enquadrada como testemunho, devendo ser apreciada não pelos critérios estéticos utilizados para a "verdadeira" literatura, mas por seu caráter de documento autêntico. Por isso, as edições de seus livros mantêm os erros de ortografia e gramática dos originais, ao contrário do que ocorre com os autores da elite, cujas obras são corrigidas por um revisor antes de chegar ao público.

O texto de Carolina Maria de Jesus não esconde sua pretensão de ser aceita como literata, manifestada desde antes de sua "descoberta", o que transparece tanto na imagem que externa de si mesma quanto no estilo, marcado pela utilização de palavras pouco usais e de metáforas, pela inversão de frases, pela referência a autores, pela hipercorreção (JESUS, 1983). Trata-se de uma estratégia de distinção voltada, em primeiro lugar, para seu próprio ambiente. "Se a autora Carolina Maria de Jesus não possui os instrumentos mais eficientes, e legítimos, para se afirmar no campo literário, a Carolina que nasce das páginas de seu livro é bastante eficaz em mostrar aos vizinhos a diferença que separa uma artista de um punhado de favelados sem eira nem beira" (DALCASTAGNÈ, 2002, p. 66). É este o seu drama: ela é capaz de virar escritora na favela, mas continua não o sendo no campo literário.

Mais do que em qualquer outro momento, esse drama transparece num trecho de um dos diários em que narra sua vida após a publicação de Quarto de despejo, que proporcionou uma relativa as- censão econômica e a saída da favela. Ela vai a uma recepção em homenagem a Clarice Lispector; lá, sente-se deslocada e mesmo hostilizada: "eu fiquei sem ação. Sentei numa poltrona e fiquei" (JESUS, 1996, p. 201). Quanto à homenageada, "não a vi. Não a cumprimentei. [...] Retornei para casa pensando no dinheiro que gastei pintando unhas e pagando conduções. Dinheiro que poderia guardar para comprar pão e feijão para os meus filhos" (idem, p. 203; ortografia e gramática corrigidas). A sentença final é reveladora. Em "Quarto de despejo", a literatura surge como o contraponto à dura privação, como promessa de superação da luta cotidiana pela sobrevivência que ela narra, página após página. Recusada como escritora, só resta a ela voltar-se novamente para a contabilidade dos trocados, para a preocupação com a necessidade mais básica (o alimento), que é o único discurso que ela tem legitimidade para proferir.

Assim, a aparente inclusão de Jesus como escritora recobre a não-aceitação de sua dicção como legitimamente literária. Ela esforça-se para adequar sua linguagem ao modelo adequado, mas nunca é o suficiente. Aliás, qualquer esforço é inútil. Quanto mais ela aproximasse-se dos modos discursivos consagrados no campo literário, mais afastar-se-ia da "autenticidade" que é, afinal, o único recurso de que dispõe para ser aceita. Seus livros são editados - alguns deles, ao menos - e até receberam alguma atenção da crítica, mas sua posição está fixada de antemão. Ela é a avis rara, que escreve sem ser escritora. Carolina Maria de Jesus é barrada na entrada; a tensão que gera é a de alguém que esmurra a porta pelo lado de fora. Ela não obriga o campo literário a admitir uma dicção diferenciada, simplesmente porque este marca-a com o emblema do não-literário.

Décadas depois, as favelas geraram um novo escritor de sucesso - Paulo Lins, autor do festejado romance Cidade de Deus (LINS, 1997). As situações são díspares, uma vez que Lins, ao contrário de Jesus, possuía educação superior e contatos nas rodas intelectuais. Mas seu livro também se beneficia da aura de autenticidade, advinda da experiência vivida, ao mesmo tempo em que o autor busca incorporar signos de literariedade que o diferenciem do mero testemunho. Sua obra é um romance, não diários. Tal como Jesus, há o uso de um vocabulário distendido, mas aqui é marcada a diferença entre a fala das personagens, eivada de incorreções e gírias, e o registro culto 
do narrador. Em especial, Lins, embora fale "de dentro", faz um recorte da vida na favela, monopolizado pela violência, que não é diferente daquele apresentado pelos escritores "do asfalto".

O sucesso de Paulo Lins na busca do reconhecimento como escritor parece ter sido bem maior que o de Carolina Maria de Jesus. Mas sua obra também se distancia bem menos das regras dominantes do campo em comparação com a dela. O contraste entre os dois autores ilustra o dilema de indivíduos de grupos marginalizados que ingressam ou pretendem ingressar em campos sociais que, de forma geral, estariam vedados a eles. A adaptação ao padrão dominante pareceria o caminho mais fácil, mas implica no abandono de sua própria especificidade - a perda das vantagens que a incorporação de novas perspectivas traria - e encontra limites, uma vez que a frustração das expectativas sobre seu diferencial também produz ônus simbólicos. A reafirmação da diferença pode representar a renovação da marginalidade, além do risco de isolá-los em suas temáticas específicas: o escritor da elite pode tratar de qualquer assunto, ainda que lhe falte a "autenticidade", mas de que pode tratar o favelado se não da favela?

E do que pode tratar a mulher na política se não de temas "femininos"? Um dos principais mecanismos de incorporação marginal dos grupos minoritários é o insulamento em nichos com escasso prestígio no campo. A experiência da presença das mulheres na política é outra ilustração nítida do fenômeno.

Não é raro que a defesa de uma presença maior de mulheres na política seja apoiada na afirmação de uma suposta diferença feminina no exercício do poder. Características maternais que, de acordo com o senso comum, são uma das marcas da "feminilidade" alcançariam a arena política. Em contraposição a seus concorrentes do sexo masculino, elas, as políticas, seriam mais altruístas, menos agressivas e menos obcecadas com a disputa pelo poder. Suas preocupações estariam voltadas para os mais frágeis. É um discurso que surge com freqüência entre as próprias mulheres na política, pois marca com positividade suas pretensas características. Mesmo a pouca experiência delas pode ganhar conotação positiva - elas não estariam contaminadas pelas práticas tradicionais, corruptas, da política feita pelos homens (PINHEIRO, 2007).
De forma mais elaborada, essa é a posição do chamado "pensamento maternal" ou "política do desvelo" ("care politics"), desenvolvida por pensadoras como Sara Ruddick (1989) e Jean Bethke Elshtain (1981), entre outras. A socialização diferenciada por que passam as mulheres engendraria uma sensibilidade e um julgamento moral específicos, opostos aos masculinos dominantes. A presença feminina possibilitaria a superação da "política de interesses", característica do mundo dos homens. Decorre daí que, uma vez alcançada a paridade de gênero nos foros decisórios, sua decorrência natural seria a alteração dos padrões dominantes no campo político, com o apaziguamento do comportamento competitivo "masculino".

A afirmação de que as mulheres possuem tais atributos morais diferenciados é questionável a partir de duas perspectivas, uma "política" e outra "empírica". Do ponto de vista político, é arriscado que feministas propaguem um tipo de discurso que, como anotou Okin (1989, p. 15), tende a ser apropriado por forças reacionárias, como a hierarquia católica, com o intuito de aprisionar as mulheres na esfera doméstica. E empiricamente é possível contestar a associação entre mulheres e uma forma determinada de fazer política. Muitas mulheres que obtiveram êxito em suas carreiras mostraram-se vinculadas ao padrão "masculino" de comportamento político - como, por exemplo, Margaret Thatcher, que foi primeira-ministra do Reino Unido de 1980 a 1991 e pode ser considerada a líder política de maior influência internacional no século XX.

Com efeito, no âmbito parlamentar, há indícios de que as mulheres ocupam-se com mais freqüência de temas ligados à área social do que àqueles vinculados diretamente ao controle do Estado e de seus recursos e à distribuição dos postos de exercício do poder. A questão que se coloca, entretanto, é se isto é uma opção ou, ao contrário, um efeito da falta de opção: as mulheres encontram nesses temas o único nicho disponível para elas no campo político (DELPHY, 1994). E, ao mesmo tempo em que são mais permeáveis à presença das mulheres, tais temas estão associados a posições menos prestigiadas do campo político. Do discurso da "política maternal" decorre, então, uma manutenção da divisão social do trabalho político que, confinando as mulheres ao âmbito das questões sociais, reserva aos homens as tarefas com maior reconhecimento social. 
Um estudo realizado a partir de uma ampla amostra de discursos pronunciados no plenário da Câmara dos Deputados revelou que, de fato, as mulheres tendem a falar mais sobre temáticas sociais (família, assistência social, educação), ao passo que os homens concentram-se nos temas de hard politics (política econômica, infraestrutura, gestão do Estado). Tal associação, no entanto, condiciona as possibilidades de avanço na carreira política. Os deputados que ocupam as posições centrais, aqueles que são reconhecidos como detentores de maior capital simbólico, vinculamse aos temas considerados masculinos. Mulheres que avançam na carreira precisam adotar o padrão masculino de ação política. A distância que separa uma Deputada mais influente de outra menos influente, no que se refere aos assuntos de seus discursos, é muito maior do que a que separa dois deputados homens. Acumular capital político, para uma mulher, significa então aproximarse do padrão tido como masculino de escolha temática.

De fato, os dados sinalizam com clareza que, à medida que o capital político cresce, o parlamentar tende a dedicar-se mais à política hard. Os temas sociais aparecem como um nicho temático interessante para iniciantes ou, de maneira mais geral, para aqueles que, encontrandose nas posições periféricas do campo político, buscam seu espaço de visibilidade em questões que são menos disputadas ou para as quais a disputa é menos qualificada. Mas o que é apenas um degrau na carreira política de um homem aparece como sendo o espaço definitivo para a ação parlamentar de uma mulher. Assim, o cruzamento entre sexo e posição no campo reforça a hipótese de que a vinculação das mulheres aos temas julgados femininos contribui para mantê-las em situação de menor prestígio e influência (MIGUEL \& FEITOSA, 2009).

Não se trata de uma opção que se resolve pela preferência da mulher política por um ou outro caminho. Existem ônus associados à escolha de uma mulher por temas vistos como masculinos, que vão desde a estigmatização (basta pensar no rótulo de "Dama de Ferro" ou na blague atribuída a Ronald Reagan, de que Margaret Thatcher seria "o melhor homem da Inglaterra") até a exclusão pura e simples. O nicho dos temas aceitos como femininos não propicia maiores vôos, mas é relativamente mais seguro para elas. A necessidade de fazer uma escolha é imposta às mulheres de uma forma muito mais veemente do que para os homens, até porque, sendo dominantes, não há tema interdito para eles - mesmo nas temáticas preferidas por elas, a maioria dos discursos é proferida por deputados do sexo masculino.

É de esperar-se que o volume da presença feminina tenha algum significado - a exclusão sistemática de menos de $10 \%$ do corpo de parlamentares das posições de elite da Câmara parece mais fácil do que a exclusão de, digamos, metade dos representantes. A experiência da obtenção do direito de voto, porém, mostra que a transformação de número em acesso não é automática. Volume importa, sim, mas não resolve. Os mecanismos de exclusão e cooptação permanecem ativos e, assim, o ingresso nos espaços de decisão é apenas um passo na busca por maior equilíbrio no exercício do poder político.

Os dados deixam claro que a vinculação entre determinadas temáticas e a progressão na carreira política é um claro exemplo do funcionamento do habitus próprio ao campo. É possível questionar se alguns dos problemas admitidos como femininos não seriam socialmente mais importantes do que os masculinos. Mas, ainda que o sejam, eles aparecem no campo com um sinal negativo. Quando as mulheres são admitidas na esfera política, elas são associadas de forma automática às posições inferiores e, justamente por isso, sua capacidade de transformar as hierarquias do campo é reduzida. Para ascender às posições centrais, têm que se curvar às disposições dominantes.

$\mathrm{O}$ insulamento das mulheres nessas temáticas, convém ressaltar, não é assumido aqui como resultado de uma perspectiva social diferenciada e sim de estereótipos de gênero. As experiências socialmente estruturadas comuns às mulheres podem contribuir para gerar uma sensibilidade e um ponto de vista diferenciados que se manifestam a respeito de um conjunto de temas que não são necessariamente aqueles considerados como femininos. A circunscrição da fala legítima das mulheres a este último não é efeito de uma perspectiva que é própria delas, mas da percepção estereotipada sobre quem elas são e como se situam na sociedade. A persistência dos estereótipos contribui para restringir a penetração das perspectivas minoritárias, que são de antemão consideradas pertinentes apenas em relação a um conjunto específico e limitado de questões. O efeito combinado e de reforço mútuo de estereótipos e 
do habitus é a principal barreira à efetivação do potencial igualitário da ampliação da presença das perspectivas dos grupos dominados.

\section{CONCLUSÕES}

Uma das maneiras de entender os processos sociais é vê-los sob a óptica do embate entre impulsos para mudança, que partem da resistência daqueles que sofrem com as injustiças, e mecanismos de reprodução da dominação, que se vinculam não apenas aos grupos em posição privilegiada, mas também às estruturas sociais estabelecidas. O conceito de perspectiva social, desenvolvido na obra de Iris Marion Young, mostrou-se útil para avançar na compreensão deste embate, mas não é suficiente para abarcar todas as suas facetas. O percurso deste artigo procurou indicar alguns de seus pontos fortes e de suas insuficiências, apontando ainda ferramentas complementares - em especial, extraídas dos trabalhos de Pierre Bourdieu - que permitiriam usar a idéia de perspectiva de forma mais complexa.

De maneira sintética, podem ser indicados três conjuntos principais de problemas que a obra de Young deixa em aberto ou resolve de maneira insatisfatória: a relação entre perspectiva e conflito social, os limites da inclusão política e o efeito das estruturas dos campos na perpetuação das desigualdades. Nesta conclusão, volto a estes três conjuntos de problemas, desenvolvendo-os de novos ângulos, de forma - espero - a reforçar os argumentos das seções anteriores.

(1) Grupos dominados não possuem apenas perspectivas diversas de grupos dominantes: possuem também interesses conflitantes. Apesar das ressalvas em contrário que ela mesma não deixou de fazer, a perda de centralidade dos conceitos de dominação e opressão na obra de Young posterior a "Justice and the Politics of Difference" fez que a idéia de perspectiva social distanciasse-se das injustiças sociais. Com isso, a variedade de perspectivas aproxima-se mais da pluralidade própria de uma sociedade multicultural e deixa desbotado o foco na estruturação das vivências de acordo com constrangimentos associados às desigualdades de poder, recursos materiais e prestígio social.

Mas não se trata somente de diversidade. A posição da mulher numa sociedade patriarcal não é apenas diferente da posição do homem. Ela carrega os signos da subalternidade. A mulher possui menos acesso às posições de poder, menos con- trole dos bens materiais. Está mais sujeita à violência e à humilhação. $\mathrm{O}$ feminino transita socialmente como a marca do inferior, do frágil, do irracional. É o outro do universal masculino. A ruptura com este estatuto subalterno implica na revisão dos privilégios masculinos. Ainda que muitos homens possam ser solidários às reivindicações femininas - e muitas mulheres ocupem postos de guardiãs do patriarcado -, há, sim, um conflito entre a emancipação delas e a permanência do papel social dominante deles.

Dizer que os grupos dominados possuem interesses conflitantes em relação aos grupos dominantes parece arriscado - afinal, não se deseja recair na percepção de que os interesses são derivados de forma automática das posições na estrutura social. Uma noção mais apropriada de interesse precisa referir-se à consciência dos agentes; caso contrário, logo estaríamos postulando a existência de um possível observador privilegiado, dotado da capacidade de localizar os interesses verdadeiros, objetivos, dos indivíduos, cuja veracidade e objetividade não estariam comprometidas mesmo se contradissessem os desejos manifestos destes mesmos indivíduos.

Não é necessário sublinhar o caráter autoritário desta posição. Mas, por outro lado, a alternativa oposta - o retorno ao dogma utilitarista de que "cada um é o melhor juiz dos seus próprios interesses" - é pelo menos igualmente insatisfatória. Interesses não são "naturais", mas construções sociais. De maneira talvez paradoxal, embora seja necessário abandonar a distinção marxista clássica entre "falsa consciência" e "verdadeira consciência", devemos manter a noção de que os interesses podem ser pouco esclarecidos, falseados ou manipulados.

A questão se coloca não em termos de interesses verdadeiros ou falsos, mas de um conjunto de preferências que se constrói de maneira mais livre ou sob maior constrangimento. $\mathrm{O}$ primeiro obstáculo ao desenvolvimento das preferências é a privação material (SUSTEIN, 2009, p. 239), que torna absolutos os imperativos da subsistência. O outro - e que talvez seja mais relevante para a presente discussão - é o que Iris Young chama de "imperialismo cultural" (YOUNG, 1990a, p. 58), vinculado ao fato de que alguns grupos monopolizam os meios de interpretação do mundo e a comunicação, portanto, produzem os artefatos culturais que contribuirão para conformar a ma- 
neira com que todos entenderão suas posições neste mundo.

Os grupos dominados, assim, precisam mais do que de um lugar para a verbalização de suas perspectivas. Precisam de espaços que lhes permitam constituir autonomamente seus interesses - o que foi chamado de "contrapúblicos subalternos" por Fraser (1992) - antes de colocá-los à prova nas arenas discursivas gerais. A ênfase exclusiva na pluralidade de perspectivas, obscurecendo o papel dos interesses, conta apenas metade da história e deixa de lado o elemento conflituoso que é inerente à atividade política.

(2) Embora importante, a incorporação de novos grupos à esfera política não resolve o problema da desigualdade de poder. O processo de debate público, em sociedades marcadas por desigualdades, não as neutraliza ou refuta. Ao contrário, ele incorpora-as de forma decisiva. Os grupos dominantes controlam mais recursos materiais, incluído aí o tempo livre, que lhes permite agir de forma eficaz na arena política. São melhor treinados na produção do discurso adequado - ou o discurso considerado adequado é mais próximo de seus padrões de fala, que são marcados positivamente, ao contrário do que ocorre com a fala dos dominados. Seus interesses são mais facilmente travestidos de interesses universais, o que é outro efeito do "imperalismo cultural": a experiência e cultura do grupo dominante é universalizada e surge como a norma (YOUNG, 1990a, p. 59).

Mesmo com os avanços da presença feminina na política, nas últimas décadas, o discurso político das mulheres continua carregando os signos de sua subalternidade. Elas movem-se dentro de um círculo restrito de temáticas que são consideradas apropriadas e que as segregam nas posições menos centrais do campo político. As marcas de "feminilidade" na fala reduzem sua legitimidade, mas a ausência delas é denunciada como uma falha daquela que não as tem: a emotividade excessiva não é pertinente num político, mas a frieza e a racionalidade não cabem para uma mulher. Em suma, o campo político impõe a elas alternativas sempre onerosas, de forma bem mais enfática do que faz com seus competidores do sexo masculino.

A ilusão da polifonia de perspectivas, como denominei neste texto, liga-se ao obscurecimento do conflito de interesses. A aposta dos teóricos deliberativos na obtenção do consenso racional, por meio da troca pública de argumentos, é o pano de fundo desses problemas; e a dificuldade de Young para desvincular-se desse ideal normativo está na fonte de muitas das insuficiências de sua obra.

Dada uma sociedade desigual, as trocas discursivas não obedecerão aos quesitos de igualdade e liberdade que a teoria deliberativa de fundo habermasiano exige. As desigualdades continuarão manifestadas, mas os grupos dominantes podem dar à imposição de seus interesses um verniz de consenso livremente produzido. É possível traçar um paralelo com o efeito da escolarização nas sociedades desenvolvidas. Conforme demonstrou uma literatura crítica, dentro da qual se destaca o trabalho de Bourdieu e Passeron (1970), as hierarquias sociais saem praticamente intactas da instituição escolar. As crianças oriundas dos grupos privilegiados possuem melhores condições de sucesso no ambiente educacional. Mas as diferenças resultantes são legitimadas, pois passam a ser atribuídas ao mérito, não mais às injustiças.

Isso não quer dizer que a ampliação da presença seja irrelevante, mas sim que é necessário não retirar das relações comunicativas "as relações de força que nelas se efetivam sob uma forma transfigurada" (BOURDIEU, 1997, p. 81). Ao isolar as trocas discursivas das desigualdades sociais, essas vertentes reproduzem o defeito que Marx criticava no pensamento liberal, a crença na possibilidade de um céu político desvinculado da terra material. Uma teoria que se deseje crítica deve começar pela negação dessa desvinculação.

(3) O campo político é um espaço social hierarquizado, que reproduz assimetrias e exclusões. A presença dos integrantes de grupos dominados nos espaços de poder não elimina, nem reduz substantivamente, por si só, a desigualdade política - apenas torna o conjunto de tomadores de decisão mais similar ao corpo social. Ela pode, sim, gerar tensões e ampliar os custos da reprodução da dominação, mas sempre na contramão dos mecanismos de exclusão e cooptação que o campo põe em funcionamento. E o entendimento desses efeitos depende da consciência da força conservadora das estruturas do campo.

A homogeneidade do grupo politicamente dominante é mantida por uma série de barreiras à ação conjunta. No caso das mulheres, em particular, eliminadas as barreiras legais, com a conquista do sufrágio feminino, permanecem os constrangimentos materiais e simbólicos que as afas- 
tam da disputa política. A demanda por presença política e as medidas associadas a ela, em particular a fixação de cotas por sexo, contrapõem-se aos efeitos desses constrangimentos. Mas as estruturas do campo político resistem à inclusão efetiva, mantendo as mulheres em posição periférica e impondo ônus simbólicos especiais à sua ação.

Aparecem aqui dois problemas interligados. $\mathrm{O}$ primeiro, abordado na seção anterior, é relacionado à opção entre estratégias afirmativas e transformadoras. Longe de negar relevância às demandas por presença política, a posição que quis desenvolver neste artigo indica que a presença é necessária, mas sua defesa não pode recusar o reconhecimento da permanência dos mecanismos de hierarquização e exclusão próprios do campo, nem ignorar que a edificação de uma ordem mais igualitária exige não apenas a redistribuição dos postos políticos entre os grupos, mas uma redistribuição geral do capital político, isto é, da capacidade de intervir no debate sobre as questões de interesse coletivo.

O segundo problema diz respeito à relação entre habitus e perspectiva. Os dois conceitos diri- gem-se a facetas diferentes da experiência social humana. Defendi a posição de que ambos são ferramentas úteis para a compreensão dos processos de produção e reprodução das desigualdades sociais em geral e da desigualdade política em particular. E avancei a hipótese, ainda muito embrionária, de que os padrões de silencialidade sistemática de perspectivas subalternas em determinados campos sociais explicam-se pela ligação, historicamente construída, entre o habitus e as perspectivas dos grupos dominantes no campo.

A obra de Iris Marion Young, tal como a de Pierre Bourdieu, constrói instrumentos que possibilitam o entendimento dos fenômenos da dominação e buscar brechas para contestá-los. A força dos mecanismos de reprodução das hierarquias dadas não permite sonhar com soluções instantâneas e definitivas. Mas é possível esperar avanços, que serão mais sólidos na medida em que reconheçam francamente a complexidade dos desafios a serem enfrentados e que se fundem no compromisso radical com a justiça, entendida como superação da opressão e da dominação historicamente constituídas.

Luis Felipe Miguel (lfelipemiguel@uol.com.br) é Doutor em Ciências Sociais pela Universidade Estadual de Campinas (Unicamp) e Professor de Ciência Política na Universidade de Brasília (UnB).

\section{REFERÊNCIAS BIBLIOGRÁFICAS}

ARAÚJO, C. 2001. As cotas por sexo para a competição legislativa: o caso brasileiro em comparação com experiências internacionais. Dados, Rio de Janeiro, v. 44, n. 1, p. 155-194. Disponível em: http://www.scielo.br/ scielo.php?script $=$ sci_arttext\&pid $=\mathrm{S} 0011$ 52582001000100006\&lng-pt\&nrm=iso\&tlng-pt. Acesso em: 3.maio.2010.

ARAÚJO, C. \& ALVES, J. E. D. 2007. Impacto de indicadores sociais e do sistema eleitoral sobre as chances das mulheres nas eleições e suas interações com as cotas. Dados, Rio de Janeiro, v. 50, n. 3, p. 535-577. Disponível em: http://www.scielo.br/pdf/dados/v50n3/ 04.pdf. Acesso em: 3.maio.2010.

BEAUVOIR, S. 2009. O segundo sexo. Rio de Janeiro: Nova Fronteira.

BICKFORD, S. 1996. The Dissonance of Democracy: Listening, Conflict, and Citizenship. Ithaca: Cornell University.
BOLAÑO, R. 2009. 2666. Barcelona: Anagrama.

BOURDIEU, P. 1979. La distinction: critique sociale du jugement. Paris: Minuit.

1989. A representação política. Elementos para uma teoria do campo político. In: O poder simbólico. Lisboa: Difel.

1997. Méditations pascaliennes. Paris: Seuil.

1998a. La domination masculine. Paris: Seuil.

1998b. Le règles de l'art: genèse et structure du champ littéraire. Paris: Seuil.

2000. Propos sur le champ politique. Lyon: Université de Lyon.

BOURDIEU, P. \& PASSERON, J.-C. 1970. La reproduction: éléments pour une théorie du système d'enseignement. Paris: Minuit. 
CORRÊA, M. 1999. O sexo da dominação. Novos Estudos, São Paulo, n. 54, p. 43-53.

DALCASTAGNÈ, R. 2003. Uma voz ao sol: representação e legitimidade na narrativa brasileira contemporânea. Estudos de Literatura Brasileira Contemporânea, Brasília, n. 20, p. 33-77.

2005. A personagem do romance brasileiro contemporâneo: 1990-2004. Estudos de Literatura Brasileira Contemporânea, Brasília, n. 26, p. 13-71.

2007. Imagens da mulher na narrativa brasileira. O Eixo e a Roda, Belo Horizonte, $\mathrm{n}$. 15, p. 127-135.

2008. Quando o preconceito se faz silêncio: relações raciais na literatura brasileira contemporânea. Gragoatá, Niterói, n. 24, p. 203219.

DELPHY, C. 1994. Feminismo e reconstrução da esquerda. Revista Estudos Feministas, Rio de Janeiro, v. 2, n. 1, p. 187-199.

ELSHTAIN, J. B. 1981. Public Man, Private Woman: Women in Social and Political Thought. Princeton: Princeton University.

FOX, R. L. \& LAWLESS, J. L. 2004. Entering the Arena? Gender and the Decision to Run for Office. American Journal of Political Science, Austin, v. 48, n. 2, p. 264-80.

FRASER, N. 1992. Rethinking the Public Sphere: a Contribution to the Critique of Actually Existing Democracy. In: CALHOUN, C. (ed.). Habermas and the Public Sphere. Cambridge, Mass.: MIT.

1997. Justice Interruptus: Critical Reflections on the "Postsocialist" Condition. New York: Routledge.

2003. Social Justice in the Age of Identity Politics: Redistribution, Recognition, and Participation. In: FRASER, N. \& HONNETH. A. Redistribution or Recognition? A PoliticalPhilosophical Exchange. London: Verso

GORZ, A. 1988. Métamorphoses du travail: quête du sens. Critique de la raison économique. Paris: Galilée.

1991. Capitalisme, socialisme, écologie: désorientations, orientations. Paris: Galilée.
HABERMAS, J. 1997. Direito e democracia: entre facticidade e validade. $2 \mathrm{~V}$. Rio de Janeiro: Tempo Brasileiro.

HOBBES, T. 1997. Leviatã. São Paulo: Nova Cultural.

JESUS, C. M. 1983. Quarto de despejo: diário de uma favelada. Rio de Janeiro: F. Alves.

1996. Meu estranho diário. São Paulo: Xamã.

LINS, P. 1997. Cidade de Deus. São Paulo: Companhia das Letras.

MARX, K. 1983. Contribuição à crítica da Economia Política. São Paulo: M. Fontes.

MIGUEL, L. F. 2000. Teoria política feminista e liberalismo: o caso das cotas de representação. Revista Brasileira de Ciências Sociais, São Paulo, n. 44, p. 91-102. Disponível em: http://www.scielo.br/pdf/rbcsoc/v15n44/ 4149.pdf. Acesso em: 3.maio.2010.

2001. Política de interesses, política do desvelo: representação e "singularidade feminina". Revista Estudos Feministas, Florianópolis, v. 9, n. 1, p. 253-267. Disponível em: http://redalyc.uaemex.mx/redalyc/pdf/ 381/38109115.pdf. Acesso em: 3.maio.2010.

2002. As duas lógicas da ação comunicativa: democracia e deliberação no debate contemporâneo. Teoria \& Sociedade, Belo Horizonte, n. 10, p. 104-143.

. 2003. Representação política em 3-D: elementos para uma teoria ampliada da representação política. Revista Brasileira de Ciências Sociais, São Paulo n. 51, p. 123-140. Disponível em: http://www.scielo.br/pdf/rbcsoc/ v18n51/15989.pdf. Acesso em: 3.maio.3010.

2005. Impasses da accountability: dilemas e alternativas da representação política. Revista de Sociologia e Política, Curitiba, n. 25, p. 165-178, nov. Disponível em: http:// www.scielo.br/pdf/rsocp/n25/31109.pdf. Acesso em: 3.maio.2010.

2006. Utopias do pós-socialismo: esboços e projetos de reorganização radical da sociedade. Revista Brasileira de Ciências Sociais, São Paulo, n. 61, p. 91-114. Disponível em: http://www.scielo.br/pdf/rbcsoc/v21n61/ a05v2161.pdf. Acesso em: 3.maio.2010. 
.2008. Political Representation and Gender in Brazil: Quotas for Women and Their Impact. Bulletin of Latin American Research, Liverpool, v. 27, n. 2, p. 197-214.

2009. Democracia, representação e comunidade. In: ARAÚJO, C. \& AMADEO, J. (orgs.). Teoria politica latino-americana. São Paulo: Hucitec.

MIGUEL, L. F. \& BIROLI, F. 2008. Gênero e política no jornalismo brasileiro. Revista Famecos, Porto Alegre, n. 36, p. 24-39, ago. Disponível em: http:// revcom.portcom.intercom.org.br/index.php/ famecos/article/viewFile/5468/4966. Acesso em: 3.maio.2010.

2009. A produção da imparcialidade: a construção do discurso universal a partir da perspectiva jornalística. In: ENCONTRO ANUAL DA ASSOCIAÇÃO NACIONAL DE PÓSGRADUAÇÃO E PESQUISA EM COMUNICAÇÃO SOCIAL, 18., Belo Horizonte, 25.jun. Anais. Belo Horizonte: Associação Nacional de Pós-Graduação e Pesquisa em Comunicação Social.

MIGUEL, L. F. \& FEITOSA, F. 2009. O gênero do discurso parlamentar: mulheres e homens na tribuna da Câmara dos Deputados. Dados, Rio de Janeiro, v. 52, n. 1, p. 201-221. Disponível em: http://www.scielo.br/pdf/dados/ v52n1/v52n1a06.pdf. Acesso em: 3.maio.2010.

MOI, T. 1999. What is a Woman? Oxford: Oxford University.

OATES, J. C. 2008. A filha do coveiro. Rio de Janeiro: Alfaguara.

OKIN, S. M. 1989. Justice, Gender, and the Family. New York: Basic.

PHILLIPS, A. 1991. Engendering Democracy. Cambridge: Polity.

1993. Democracy and Difference. University Park: Pennsylvania State University.

. 1995. The Politics of Presence. Oxford: Oxford University.

1999. Which Equalities Matter? Cambridge: Polity.

PINHEIRO, L. S. 2007. Vozes femininas na política: uma análise sobre mulheres parlamentares no pós-Constituinte. Brasília: Secretaria
Especial de Políticas para as Mulheres.

PITKIN, H. F. 1967. The Concept of Representation. Berkeley: University of California.

PRZEWORSKI, A. 1985. Capitalismo e socialdemocracia. São Paulo: Companhia das Letras.

RAWLS, J. 1997. Uma teoria da Justiça. São Paulo: M. Fontes.

2000. O liberalismo político. São Paulo: Ática.

ROSANVALLON, P. 1998. Le peuple introuvable: histoire de la représentation démocratique en France. Paris: Gallimard.

ROUSSEAU, J.-J. 1964. Du contract social. In: mard. . Euvres complètes. T. III. Paris: Galli-

RUDDICK, S. 1989. Maternal Thinking: Toward A Politics of Peace. Boston: Beacon.

SANDEL, M. 1998. Liberalism and the Limits of Justice. Cambridge: Cambridge University.

SPIVAK, G. C. 1998. Can the Subaltern Speak? In: NELSON, C. \& GROSSBERG, L. (eds.). Marxism and the Interpretation of Culture. Urbana: University of Illinois.

SUSTEIN, C. R. 2009. Preferências e política. Revista Brasileira de Ciência Política, Brasília, n. 1, p. 219-254. Disponível em: http:// rbcp.unb.br/artigos/rbcp-n1-10.pdf. Acesso em: 9.maio. 2010.

URBINATI, N. 2000. Representation as Advocacy: a Study of Democratic Deliberation. Political Theory, Thousand Oaks, v. 28, n. 6, p. 758786.

2006. Representative Democracy: Principles and Genealogy. Chicago: University of Chicago.

VAN PARIJS, P. 1992. Basic Income Capitalism. Ethics, Chicago, v. 102, n. 3, p. 465-484.

VAN DER VEEN, R. J. \& VAN PARIJS, F. 1987. A Capitalist Road to Communism. Theory and Society, Dordrecht, v. 15, n. 5, p. 635-655.

WILLIAMS, M. S. 1998. Voice, Trust, and Memory: Marginalized Groups and the Failings of Liberal Representation. Princeton: Princeton University. 
YOUNG, I. M. 1990a. Justice and the Politics of Difference. Princeton: Princeton University.

1990b. Throwing Like a Girl and Other Essays in the Feminist Philosophy and Social Theory. Bloomington: Indiana University.

1997. Intersecting Voices: Dilemmas of Gender, Political Philosophy, and Policy. Princeton: Princeton University.
2000. Inclusion and Democracy. Oxford: Oxford University.

2001. Activist Challenges to Deliberative Democracy. Political Theory, Thousand Oaks, v. 29 , n. 5, p. 670-690.

2005. On Female Body Experience: "Throwing Like a Girl" and Other Essays. Oxford: Oxford University.

\section{OUTRA FONTE}

Política é coisa de homem? 2006. Veja, São Paulo, n. 1966, 26.jul, p. 45. Disponível em: http:/ /veja.abril.com.br/acervodigital/ home.aspx? edicao $=1966 \& p g=06$. Acesso em: 9.maio. 2010 . 
SOCIAL PERSPECTIVES AND SYMBOLIC DOMINATION: WOMEN'S POLITICAL PRESENCE, IN IRIS MARION YOUNG AND PIERRE BOURDIEU

\section{Luis Felipe Miguel}

This article looks at women's political participation and presence within political power. In this regard, we discuss the tension between the emancipatory potential offered by incorporation of multiple perspectives into political debate and the reproductive action of the field. Starting from a look at causes that, in our view, may be responsible for the relative absence of women in decision-making circles and for their alleged "lack of interest" in politics, we discuss perspectives that are, in one way or another, geared toward solving (improving) this situation. The article is organized into three sections. In the first, we defend the position that a more promising way to justify the need for women's presence is offered by understanding that spaces of deliberation should house a plurality of relevant social perspectives - a concept that can be most clearly associated with the work of the U.S. political theoretician, Iris Marion Young. In the second section, we discuss some of the problems contained within this concept, most particularly, a certain naiveté present in the ideal that derives from it: the creation of a pluralist discussion and decision-making spaces resulting from electoral quotas. We use the notion of "field", taken from Pierre Bourdieu's work, in order to cleanse Young's ideas of such naiveté. Within the third section, we introduce an additional element: Nancy Fraser's distinction between "affirmative" and "transforming" policies. As preliminary conclusions, we end with an evaluation of the limitations and potentials of a politics based on the defense of increased presence of "social perspectives".

KEYWORDS: social perspectives; political field; political representation; Iris Marion Young; Pierre Bourdieu. 


\section{PERSPECTIVES SOCIALES ET DOMINATION SYMBOLIQUE: LA PRÉSENCE POLITIQUE DES FEMMES ENTRE IRIS MARION YOUNG E PIERRE BOURDIEU}

\section{Luis Felipe Miguel}

Cet article parle de la participation politique des femmes et leur présence dans le pouvoir politique. Dans ce thème, on discute la tension entre le potentiel d'émancipation promis par l'incorporation de multiples perspectives au débat politique et l'action reproductrice du domaine. En partant des causes, qu'à notre avis, sont responsables par la relative absence de femmes des cercles de décision et pour leur « désentérêt » par la politique ; nous discutons les perspectives orientées, d'une façon ou d'une autre, pour la solution (amélioration) de cette situation. L'article s'organise en trois parties. Dans la première, on défend l'avis de que la voie la plus prometeuse pour justifier la nécessité de la présence des femmes, passe par la comprehension de que les espaces de délibération doivent loger une pluralité de perspectives sociales pertinentes - un concept associé, surtout, à l'oeuvre de la théoricienne américaine Iris Marion Young. Dans la deuxième partie, on discute quelques problèmes de ce concept, particulièrement, une certaine naïveté qui marque un idéal dérivé à partir de lui : la génération d'un espace pluriel de discussion et de prise de décisions en fonction de l'adoption de quotas électoraux. On utilise le concept de « domaine », extrait de l'oeuvre de Pierre Bourdieu, pour dépurer les idées de Young sur cette naïveté. Dans la trosième partie, on introduit un élement de plus : la distinction, présentée par Nancy Fraser, entre « politiques affirmatives » et « politiques de transformation $»$. Il en résulte, de façon préliminaire, avec un équilibre des limites et des potentialités d'une politique basée sur la défense de l'ampliation de la présence de «perspectives sociales ».

MOTS-CLES: perspective sociale; domaine politique; représentation politique; Iris Marion Young; Pierre Bourdieu. 